\author{
UNIVERSIDADE DE SÃO PAULO \\ FACULDADE DE FILOSOFIA, LETRAS E CIÊNCIAS HUMANAS \\ DEPARTAMENTO DE LETRAS MODERNAS \\ PROGRAMA DE PÓS-GRADUAÇÃO EM LÍNGUA E LITERATURA ITALIANA
}

ANTONIO MARCIO ATAIDE

No deserto a esperar pelos Tártaros: Um estudo sobre o tempo no romance

Il deserto dei Tartari de Dino Buzzati

v. 1

São Paulo

2009 
UNIVERSIDADE DE SÃO PAULO

FACULDADE DE FILOSOFIA, LETRAS E CIÊNCIAS HUMANAS

DEPARTAMENTO DE LETRAS MODERNAS

PROGRAMA DE PÓS-GRADUAÇÃO EM LÍNGUA E LITERATURA ITALIANA

\title{
No deserto a esperar pelos Tártaros: Um estudo sobre o tempo no romance \\ Il deserto dei Tartari de Dino Buzzati
}

\begin{abstract}
Antonio Marcio Ataide
Dissertação apresentada ao Programa de Pós-Graduação em Língua e Literatura Italiana do Departamento de Letras Modernas Da Faculdade de Filosofia, Letras e Ciências Humanas da Universidade de São Paulo, Para obtenção do título de Mestre em Letras.
\end{abstract}

Orientador: Profa. Dra. Doris Nátia Cavallari

v. 1

São Paulo

2009 


\section{Resumo}

O presente trabalho propõe um estudo sobre questões de tempo em narrativa no romance Il deserto dei Tartari de Dino Buzzati. Terceiro romance do escritor italiano, publicado em 1940, narra a saga de um oficial de exército que presta serviço a vida inteira em um forte localizado na fronteira norte de seu país que guarda um imenso deserto a sua frente, de onde um dia uma invasão inimiga é esperada. Procuramos estudar no texto, alegoria da condição humana, as diversas relações do homem com seu maior inimigo, o tempo. Tratamos no primeiro capítulo dos trabalhos sobre tempo e narrativa, a partir de vários estudiosos que se ocuparam desse tema e que nos auxiliam em todo o trabalho. No segundo capítulo estudamos mais cuidadosamente a questão do tempo no interior da narrativa, ampliando a análise proposta, no terceiro capítulo, com uma discussão sobre as relações do tempo com o espaço e com o homem.

Palavras-chave: Narrativa Italiana; Dino Buzzati; Il deserto dei Tartari; Tempo; Narrativa.

\section{Riassunto}

Questo lavoro propone uno studio sul tempo narrativo nel romanzo Il deserto dei Tartari di Dino Buzzati. Il terzo romanzo dello scrittore italiano pubblicato nel 1940 racconta la vicenda di un ufficiale dell'esercito che per tutta la sua vita serve in una fortezza della frontiera nord del suo paese, la quale sta di fronte ad un grandissimo deserto da cui un giorno dovrebbe arrivare un'invasione nemica. Si cerca di studiare in questo romanzo, allegoria dell'umana condizione, le diverse relazioni dell'uomo con il suo più grande nemico: il tempo. Si discutono nel capitolo primo alcune teorie sul tempo e la narrativa di diversi studiosi che hanno sviluppato questo tema. Le loro teorie sono la base per l'analisi proposta. Nel secondo capitolo si studia più accuratamente il problema del tempo all'interno di questa narrativa sviluppando poi l'analisi proposta, nel capitolo terzo, propone una discussione sulle relazioni del tempo sia con lo spazio sia con l'uomo.

Parole chiavi: Narrativa Italiana; Dino Buzzati; Il deserto dei Tartari; Tempo; Narrativa. 
A minha mãe, Maria, a minha avó, Francisca. 
Agradeço,

À CAPES, pelo financiamento parcial do meu projeto de pesquisa,

Aos colegas e amigos de Graduação, por existirem,

Aos colegas e amigos de Pós-Graduação Maria Célia, Ivair, Raquel, Sandra Savizzo, Sandra Gaboardi, Eloína, Paolo, Érica, Jaqueline, Cosimo, pelo alegre e agradável convívio,

Um agradecimento especial aos amigos Francisco, Patricia e Dayse, por nunca medirem esforços para facilitar minha vida em São Paulo,

Aos professores Maurício Santana Dias e Júlio César Pimentel Pinto Filho, pelo exemplo que são para mim,

Aos professores da área de italiano do Departamento de Letras Modernas da USP, que de diversas formas me ajudaram,

Às professoras da área de italiano do Departamento de Letras Modernas do IBILCE, que sempre me ajudaram,

A Maurizio Babini, por apostar no menino espevitado, por me apresentar ao universo de Buzzati e, sobretudo, pela amizade,

À Doris, pela liberdade, confiança e paciência com as quais me orientou. 
"Ego vox clamantis in deserto"

(João 1, 23, Vulgata) 


\section{Sumário}

$\begin{array}{ll}\text { Introdução } & 8\end{array}$

$\begin{array}{ll}\text { Capítulo } 1 \mathrm{O} \text { tempo na narrativa } & 10\end{array}$

1. O tempo na narrativa 11

1.1. Dino Buzzati e Il deserto dei Tartari 11

1.2. Ricoeur e o privilégio da narrativa 14

1.3. A importância do tempo na narrativa 16

1.4. A manipulação temporal 20

Capítulo 2 A ordenação da intriga 31

2. A ordenação da intriga $\quad 32$

2.1. Disposição dos episódios 32

2.2. Arquitetura narrativa 50

Capítulo 3 Relações tempo-espaço-homem 62

3. Relações tempo-espaço-homem 63

3.1. Imagens do tempo 63

3.2. Tempo no espaço 68

3.3. O tempo e as personagens 75

$\begin{array}{ll}\text { Considerações finais } & 88\end{array}$

$\begin{array}{ll}\text { Bibliografia } & 91\end{array}$ 


\section{Introdução}

Desde a primeira leitura do romance Il deserto dei Tartari de Dino Buzzati o ponto que mais nos chama atenção é o escoar, em poucas linhas, de 15 anos da vida de Giovanni Drogo e de seus colegas da fortaleza Bastiani. A grande alegoria sob vestes militarescas é por si só matéria fecunda a debates, mas este modo particular de tratar o tempo narrativo é o núcleo fundador da necessidade de realizar este trabalho.

Um estudo sobre o tempo em Il deserto dei Tartari se fez então necessário, pois apresentava a possibilidade de compreender de onde vinha aquele poder sobre o tempo que Tomas Mann chama de "feitiço hermético". As pesquisas no campo das questões temporais em narrativa revelaram, pouco a pouco, que tínhamos inadvertidamente escolhido um desafio maior do que supúnhamos, mas igualmente fascinante.

Inicialmente, fixamo-nos nas categorizações temporais no interior da narrativa empreendidas por Gerard Genette e depois nos desenvolvimentos desse tema por A. A. Mendilow, passando, a seguir, pela leitura da monumental obra de Paul Ricoeur, a qual nos apresentou uma perspectiva mais clara sobre o tema, além de permitir um primeiro contato, por exemplo, com as indagações de Santo Agostinho e com a filosofia ontológica de Martin Heidegger.

Genette é quem nos auxilia na maior parte deste trabalho. As categorias por ele levantadas e desenvolvidas são de fundamental importância para compreender a arquitetura organizadora da obra e a partir delas entender o Deserto como um texto literário habilmente construído e validá-lo enquanto obra de arte. 
A obra de Ricoeur também é de grande importância para a organização formal de nossa análise, pois a argúcia de seus estudos em demonstrar como a narrativa refigura a experiência da temporalidade, conferindo ao tempo na narrativa uma totalidade que não se pode verificar na realidade, eleva-a a condição de pensamento exploratório das questões temporais, questão fundamental para se entender a importância do tempo na narrativa.

No primeiro capítulo desse trabalho traçaremos breves considerações sobre o romance e, a seguir, trataremos mais atentamente das questões teóricas que nortearam a análise. No segundo capítulo, que chamamos de "ordenação da intriga" apresentaremos o romance capítulo a capítulo, procurando avaliar a importância do tempo na seqüência narrativa da trama, sempre apoiados nas teorias anteriormente apresentadas. O terceiro capítulo amplia a análise proposta com uma avaliação da importância do espaço para o desenvolvimento da tessitura narrativa. Finalmente, apresentaremos as considerações finais sobre nossa leitura crítica sobre Il deserto dei Tartari. 


\section{Capítulo 1}

\section{O tempo na narrativa}

"O que é, afinal, o tempo?

Se ninguém me pergunta, sei; se alguém me pergunta e quero explicar, não sei mais"

(S. Agostinho, Confissões, livro XI, 14, 17) 


\section{O tempo na narrativa}

Neste primeiro capítulo, após uma breve introdução sobre Dino Buzzati e o romance que será objeto de nossos estudos, desenvolveremos mais detalhadamente as questões teóricas sobre tempo e narrativa, desde sua questão fundamental, trabalhada por Paul Ricoeur, qual seja, as vantagens que a narrativa ficcional tem em relação a outras formas de produção de conhecimento, como a Historiografia ou a Filosofia, no que diz respeito ao tratamento temporal. Investigaremos também questões de ordem técnica no romance em estudo, com base nos estudos de narratologia empreendidos por Gérrard Genette e A. A. Mendillow, como por exemplo, a importância do tempo como elemento organizador da narrativa, o conceito de cronologia, os mecanismos de embreagem temporal (ordem, duração e freqüência), além do comportamento dos tempos verbais no discurso narrativo.

\subsection{Dino Buzzati e Il deserto dei Tartari}

O terceiro romance do escritor italiano Dino Buzzati (1906-1972), Il deserto dei Tartari, lançado em 1940 e precedido por Bàrnabo delle montagne (1933) e Il segreto del Bosco Vecchio (1935), narra a saga de Giovanni Drogo, oficial de exército obrigado a prestar serviço em um forte isolado, a Fortaleza Bastiani, na fronteira norte de seu país com o reino vizinho. Lá se vê na condição de esperar que de um deserto venha uma agressão inimiga, hipótese que pouco a pouco começa a ganhar contornos verossímeis. $\mathrm{Na}$ doentia esperança de uma glória futura consuma toda sua vida a esperar pelos 
Tártaros que do deserto nunca vêm, até encontrar-se finalmente com o evento mais importante (e inevitável) do destino de um homem: a morte.

Comparando-se com os dois primeiros romances, o Deserto apresenta um enxugamento, quase uma "desidratação" do clima e da ambientação fantástica. Em Guida alla lettura di Buzzati (TOSCANI, 1987. p. 147) descobrimos que em relação a seu estilo e a sua forma de conceber o fantástico, Buzzati declara que quanto mais fantástico for o conteúdo, mais a narração deve ser nua, simples e minguada. Buzzati, no percurso que vai da magnitude das montanhas (Bàrnabo delle montagne), passando pela riqueza da floresta (Il segreto del Boscho Vecchio), chega à aridez do deserto, de onde nos chegam imagens secas e esguias, porém prenhes de poeticidade e simbologia. Como defende Danstrup, no artigo "Buzzati e Calvino: due scrittori e due concezioni del fantastico" (DANSTRUP, 1992, p. 137 et seq.), a narrativa se apodera do leitor levando-o, sem que este o perceba, aos limites do fantástico, alheio ao fato de que a realidade foi já deixada para trás. De fato, Buzzati prefere sempre permanecer na fronteira; avançá-la é proibido.

O romance é permeado por um clima de ambígua esperança e eventos simetricamente dispostos, narrados em sua superfície textual de maneira poética, ora com um comentário lírico, ora reflexivo do narrador, estilo definido por Marcello Carlino como "spenta prosa d'arte" ["prosa literária esmaecida”] (CARLINO, 1976, p. 74). Nesta prosa poética o fio condutor é um narrador que não participa dos eventos, mas segue-os de perto, traduzindo em sua narração os anseios e as angústias do protagonista e dos demais homens do forte, convertendo-se em seu porta-voz. 
O romance foi assim recebido por Pietro Pancrazi num ensaio do mesmo ano do

lançamento:

Mi pare certo che Il deserto dei Tartari di Dino Buzzati sia uno dei romanzi più singolari che si siano pubblicati da noi negli ultimi anni. Romanzo simbolico? romanzo satirico-umoristico? romanzo allegorico? romanzo surrealista? romanzo d'avventura, o almeno di quella rientrata avventura che spesso è la vita? Tutte queste definizioni (e l'ultima più delle altre) sono in qualche modo ammissibili, perché tutte rendono un colore o un momento del romanzo di Buzzati; ma nessuna può bastare da sola, perché nessuna calza fino in fondo. (PANCRAZI, Apud CARLINO, 1976, p. 89).

Essas observações apontam para a plurisignificação de Il deserto dei Tartari.

Com efeito, trata-se de um romance repleto de passagens simbólicas, de certo teor satírico-humorístico, talvez um tanto irônico em seu todo e, principalmente, alegórico, como já acenava de antemão o próprio Buzzati em uma entrevista:

Lo spunto del romanzo nacque dalla monotona routine redazionale notturna che facevo a quei tempi. Molto spesso avevo l'idea che quel tran-tran dovessi andare avanti senza termine e che mi avrebbe consumato così inutilmente la vita. È un sentimento comune, io penso, alla maggioranza degli uomini, soprattuto se incasellati nell'esistenza ad orario nelle città. La trasposizione di questa idea in un mondo militare fantastico è stata per me quasi istintiva. (BUZZATI, D. Il deserto dei Tartari. Milano: Mondadori, 2004, quarta capa $\left.{ }^{1}\right)$.

Um romance de aventura? A ressalva de Pancrazi é válida e Il Deserto é, como afirma paradoxalmente Biondi, um romance de aventura esvaziado, em que faltam os ingredientes essenciais (BIONDI, 1992, p. 45). Estas e outras definições seriam válidas para se descrever o que é Il deserto dei Tartari, mas nenhuma por si só bastaria a esta empresa: estudar esse romance sob qualquer ponto de vista implica várias outras renúncias.

\footnotetext{
${ }^{1}$ Esta é a edição utilizada em nosso trabalho. A partir daqui indicaremos nas demais citações de Il deserto dei Tartari apenas o número das páginas.
} 


\subsection{Ricoeur e o privilégio da narrativa}

Paul Ricoeur, em sua fundamental obra Tempo e narrativa (RICOEUR: Tomo I, 1994; tomo II, 1995; Tomo III, 1997), trata a questão entre os termos do título a partir dos resultados das indagações sobre o tempo, feitas por Santo Agostinho, no livro XI das Confissões. Aos paradoxos agostinianos, Ricoeur contrapõe a ordem que a formação da intriga, descrita na Poética de Aristóteles, confere à experiência temporal. A partir do conceito aristotélico de mimeses, ao qual propõe uma nova e complementar interpretação, demonstra como a reconfiguração da experiência do tempo pela narrativa resolve, poeticamente, as aporias levantadas pelas investigações de Agostinho de Hipona. A não observância da cronologia é uma marca desta obra, advertida, obviamente, por seu autor. Destarte, trata a Poética como se fosse uma resposta às indagações das Confissões, num belo exercício de abstração.

$\mathrm{O}$ estudioso francês demonstra a importância dos estudos agostinianos sobre o tempo, responsáveis pela fundação de uma dupla temporalidade — uma objetiva e outra subjetiva, em outros termos, um tempo pessoal e um tempo público - o que se opõe à concepção clássica de tempo, entendida desde os gregos como "algo do movimento", cuja referência era externa, em uma nova e revolucionária concepção, na qual o eixo de referência muda para o interior do indivíduo, constituindo-se como um momento fundamental para a mentalidade ocidental. Para Agostinho, medir o tempo deixa de ser observação externa e passa a ser operação ativa do espírito, de modo que a relação temporal está ligada a quem vivencia esta experiência, numa concepção de tempo decididamente individualizada e que não se identifica com o tempo de outros. À padronização do tempo público, o filósofo denuncia a miríade dos múltiplos tempos pessoais. 
As indagações de Agostinho apresentam, porém, paradoxos e dificuldades lógicas insuperáveis — as chamadas aporias —, como a questão ontológica sobre a existência ou não do tempo, ou a impossibilidade de percebê-lo pelos sentidos humanos; logo, o fato de se medir algo que não se sente e que provavelmente não exista é perturbador para Agostinho, daí sua célebre indagação: “O que é, afinal, o tempo? Se ninguém me pergunta, sei; se alguém me pergunta e quero explicar, não sei mais" (Confissões, livro XI, 14, 17. Apud RICOEUR, 1994). Tais aporias, ao longo da história do pensamento ocidental, serão retomadas por filósofos como Kant, Hegel, Heidegger e Husserl, os quais também têm seus trabalhos considerados por Ricoeur em sua obra.

Às aporias resultantes das investigações filosóficas sobre o tempo, Ricoeur opõe o que entende ser um privilégio da narrativa nesse campo. Para ele, o tecer da intriga, que é a formação do enredo, descrito pela Poética de Aristóteles tem a virtude de dar ao tempo uma forma e uma ordem que este desconhece na realidade e que o discurso fenomenológico não consegue explicar em sua totalidade. Ao tempo plural e amorfo da realidade, a narrativa apresenta sua síntese homogênea num tempo ordenado, reconfigurado, um tempo, enfim, humanizado, em que o enredo interliga numa totalidade temporal os acontecimentos, o conteúdo da história, organizando o tempo de uma forma que se possa vê-lo como que materialmente. Em outras palavras o enredo extrai dos acontecimentos do tempo da história uma unidade e uma totalidade temporal, configurando-os no tempo da narrativa. Enfim, o enredo opera uma mediação entre narrativa e história a fim de torná-los uma forma compreensível.

O privilégio da narrativa de poder totalizar temporalmente a experiência, algo impossível na realidade, explica porque uma isomorfia entre os tempos narrativos e o da realidade é uma empresa à qual se deve logo renunciar pelo fato de realidade e 
linguagem serem elementos de natureza diversa. Esta operação é realizada pela organização de fatos e eventos em um discurso narrativo, mas essa passagem exige certo cuidado, pois aqui não se veicula a realidade, mas sua analogia, sua representação.

Ricoeur elege como exemplos para sua análise a maneira como três dos maiores romancistas do século XX — Marcel Proust, Thomas Mann e Virginia Woolf — levam a termo essa espécie de transporte de um tempo para outro, além dos ajustes necessários para que esse elemento do mundo externo organize-se em um mundo de outra ordem, qual seja, o da linguagem. O fato é que há uma relação fundamental entre a linguagem e o tempo, aquela possui propriedades deste, como demonstra, por exemplo, a obra Laocoonte de G. E. Lessing (LESSING, 1998). Portanto, para Ricoeur, refigurar e ordenar o tempo, um elemento da realidade em termos narrativos, é um dos privilégios da narrativa, o que a eleva, segundo Ricoeur, à categoria de pensamento exploratório sobre o tempo. Ou, nas palavras de Benedito Nunes, "a literatura iluminando a filosofia" (NUNES, 1995, p. 84).

\subsection{A importância do tempo na narrativa}

O tempo é, inegavelmente, um componente essencial à composição narrativa, é seu elemento fundante e estruturante. Para A.A. Mendilow, em $O$ tempo e o romance (MENDILOW, 1972), essa relação torna-se mais explícita no século passado. Ele faz o diagnóstico de algo que batizou de "a obsessão do século XX pelo tempo" (Ibidem, p. 9) e, embora seja evidente que a percepção da importância do tempo não é um primado do último século, é nele que uma nova e radical concepção do tempo se verifica. Com o progresso tecnológico, o tempo conquista o espaço, encurtando fronteiras, diminuindo 
intervalos de produção; tal fenômeno também é observável na narrativa de fícção, sobretudo no romance, objeto de estudo do teórico inglês.

O tempo no século XX é um tempo que vertiginosamente se acelera, fruto de um mundo mais dinâmico e com um maior número de acontecimentos por período de vida do que nos séculos passados. Nesse sentido, Ricoeur afirma que essa aceleração tem uma forte ligação com a noção de progresso (RICOEUR, 1997, p. 364). Mas a "resposta" da literatura a esse fenômeno externo, antes de adesão ou apologia, é irônica. Nesse sentido, ao invés de ufanismo ante aos avanços da civilização, o sentimento provado diante da aceleração do tempo nos lances finais de $I l$ deserto dei Tartari é o de angústia, pois acelerar o tempo é apressar o encontro com a morte.

Mas o tempo é antes de tudo um elemento implícito da narrativa, um constituinte natural dentro de uma composição de linguagem que tem, ela também, natureza temporal. O tempo na narrativa tem papel de ajustador da trama, alinhavando os episódios e unindo um evento ao outro, função que fica clara, por exemplo, no capítulo XI do Deserto, já que a introdução deste capítulo não deixa dúvidas de qual é o intervalo de tempo entre o que fora até então relatado e o que será narrado a seguir: "quasi due anni dopo Giovanni Drogo dormiva una notte nella sua camera della Fortezza.” (p. 78).

Porém estes ajustamentos seguem uma ordem cronológica, seja ela linear (como é o caso do Deserto) ou não. Para Heidegger (Apud RICOEUR, 1997), o tempo cronológico é baseado na sucessão de intervalos regulares, o que lhe confere contornos concretos, porém o lastro de cada intervalo é arbitrário, ainda que possuam referências ditas "naturais" e relativamente constantes, como a duração do dia ou o movimento dos 
astros celestes. Heidegger, além de denunciar a arbitrariedade dessas convenções, chama a atenção também para o falso prestígio daquilo que chama de tempo vulgar, pois vulgarizando o tempo em relógios e calendários, o homem regula sua vida social, porém esse tempo é apenas uma escala da experiência temporal interior, e a grande importância dada a esse tempo esconde um engodo porque a ilusão de tempo controlado oblitera a marcha rumo ao exaurir da vida humana. O prestígio que o tempo vulgar goza na sociedade contemporânea encontra eco no seguinte trecho do capítulo XXII:

Facevano il solito loro servizio senza entusiasmo, si rallegravano anzi quando sugli ordini del giorno compariva il nome di un mese nuovo, quasi avessero fatto un guadagno. Tanto di meno da passare alla Fortezza Bastiani, calcolavano. Essi avevano dunque un loro punto di arrivo, mediocre o glorioso che fosse, di cui sapevano accontentarsi. (p. 188).

Se o calendário marca momentos de alegria no lento escoar do tempo, também significa meses a menos na corrida inevitável para a morte, armadilha da qual Giovanni Drogo não soube escapar. O protagonista, ao aderir ao tempo público e ordenado da fortaleza, é engolido pela miragem de estar imerso e seguro em um tempo coletivo, de poder se camuflar nele, porém não se dá conta de que o verdadeiro tempo está mesmo dentro de si próprio, a temporalidade fundamental que o leva rumo à morte.

O tempo vulgar para Heidegger, ou histórico para Hegel, é também matéria analisada por Ricoeur, que debate os trabalhos hegelianos sobre as formas públicas de medição do tempo, como o relógio e o calendário. Estes meios de se medir o tempo são os instrumentos dos quais se serve a historiografia para organizar os eventos por ela estudados, é a databilidade, computabilidade do tempo vulgar e público a serviço da memória coletiva. Ricoeur, nesse sentido, comenta a relação dos três romances de que trata com o tempo histórico: 
Assim, a intriga de Msr Dalloway é nitidamente situada depois da Primeira Guerra Mundial, exatamente em 1923, e se desenrola no quadro monumental do que ainda era a capital do Império Britânico. Da mesma forma, as aventuras de Hans Castorp, em Der Zauberberg, pertencem claramente ao período imediatamente anterior à guerra e desembocam explicitamente na catástrofe de 1914. Quanto aos episódios de $A$ la recherche, eles se repartem em antes e depois da primeira guerra mundial; os desenvolvimentos do caso Dreyfus fornecem pontos de referência cronológicos fáceis de identificar, e a descrição de Paris durante a guerra se insere num tempo expressamente datado. (RICOEUR, 1997, p. 220).

Porém ficção e historiografia têm compromissos diferentes com o tempo histórico, assim como diversos são, também, seus compromissos com a realidade, com o registro dos fatos. A ficção subverte sua relação com o tempo histórico, pois este passa a ser subordinado àquela, do contrário, a literatura estaria entrando nos domínios de uma outra disciplina, e a menção a fatos datáveis - e a espaços reconhecidamente existentes como Londres ou Paris — é mera ancoragem histórica com escopos de verossimilhança, com o intuito de inscrever a narrativa em um tempo-espaço que o leitor considere como reais e existentes fora da ficção. Já o Deserto, nesse particular, comporta-se de maneira um pouco diferente, uma vez que as ações descritas no romance desenrolam-se em um tempo-espaço não identificáveis no mundo externo à narrativa. Para Claudio Toscani deve-se situar a história do romance de Buzzati "in uno sfuocato trapasso di secolo tra Otto e Novecento" (TOSCANI, 1987, p. 55). Antonio Candido (1990, p. 66) complementa e desenvolve melhor esta idéia, atentando para fatos como o de pessoas andarem a cavalo, da existência de carruagens, da luneta de um só canhão, do caráter arcaico das armas além de outros aspectos que contribuem para a construção de um mundo em que é difícil precisar data e local.

O fato é que buscar ancorar a história do Deserto em nosso tempo-espaço é empresa espinhosa, a que se deve renunciar de antemão, sob pena de perder-se em uma viagem sem retorno — como a que empreendeu o próprio Giovanni Drogo —; apesar da 
grande semelhança com nosso mundo, as ações desse romance desenrolam-se em um tempo-espaço outros, num mundo especular ao nosso, mas de reflexo esguio, distorcido, embaçado. A figura do espelho está sempre presente no texto, sempre a indicar uma presença incômoda, refletindo imagens indesejadas, desde o início até o desfecho da narrativa.

\subsection{A manipulação temporal}

Para Benedito Nunes (1995), reconfigurar o tempo é um imperativo para a narrativa, e essa operação se dá de várias formas, já que, ao contrário de seu comportamento amorfo na realidade, o tempo organizado em uma narrativa é, ao contrário, plural, multiforme. Mendilow (1972) afirma que o romance é gênero literário de maior amplitude temporal, além disso, em seu interior, o tempo é também, mais heterogêneo, pois a consciência narrativa tem à sua disposição diversas formas de apresentar o tempo em cada um dos eventos que constituem a trama, operando uma embreagem temporal que está a serviço de uma maior eficácia para a veiculação de sentidos, como veremos adiante.

Para Gérard Genette (1979), toda narrativa pressupõe pelos menos dois tempos, já que há o tempo daquilo que se conta e o tempo que se leva para contá-lo, uma das funções da narrativa é cambiar um tempo num outro tempo. Esta dualidade temporal é evidenciada na oposição elaborada pelo teórico alemão Günter Müller entre tempo da história (Erzählte Zeit) e tempo da narrativa (Erzählzeit), distinção assumida também por Genette. Mas esses tempos jamais coincidem, nunca poderão coincidir. O tempo da narrativa é, afinal, o que se consome em sua leitura, porém esse tempo metonímico da 
leitura é o único ao qual temos acesso, os outros tempos são, portanto, abstrações que o têm como ponto de partida. Este pseudo-tempo — o da narrativa — porém deve ser tomado como um tempo verdadeiro.

É a partir dessa relação entre tempo da história e tempo da narrativa que Genette estuda as questões de ordem, ou seja, a seqüência temporal em que se sucedem os acontecimentos na história e a ordem pseudo-temporal da sua disposição na narrativa; trata também da relação entre a duração variável desses acontecimentos ou segmentos diegéticos, e sua pseudo-duração (ou extensão de texto) na narrativa, relação, pois, de velocidade - cena, sumário, elipse e pausa; e finalmente a relação de freqüência, ou seja, da capacidade de repetição da história e as da narrativa.

Sobre a ordem temporal de uma narrativa Genette postula que:

Estudar a ordem narrativa é confrontar a ordem de disposição dos acontecimentos ou segmentos temporais no discurso narrativo com a ordem de sucessão desses mesmos acontecimentos ou segmentos temporais na história, na medida em que é indicada explicitamente pela própria narrativa ou pode ser inferida deste ou daquele indício indirecto. (Ibidem, p. 33).

Como observamos a seguir, não há diferenças consideráveis entre história e narrativa em Il deserto dei Tartari, pois no texto está claro que a ordem dos eventos na narrativa é a mesma da história.

Genette chama de anacronias as formas de discordância entre a ordem da história e a da narrativa, o que dá a entender, segundo ele, a existência de uma espécie de "grau zero", ou seja, um estado de perfeita coincidência entre narrativa e história, porém de cunho apenas hipotético, mas que serve de apoio teórico. As anacronias estão presentes em toda a história do discurso épico, desde a convenção de se iniciar a 
Epopéia in media res até as diversas dessemelhanças entre história e narrativa do discurso romanesco, recurso, enfim, de grande tradição na narrativa literária.

Toda anacronia representa uma discordância entre história e narrativa, constitui uma narrativa temporalmente secundária em relação à primeira, na qual se insere e à qual é subordinada. As principais anacronias — verdadeiras manobras narrativas descritas por Genette são a prolepse e a analepse. A prolepse conta ou evoca de antemão um acontecimento futuro, antecipando-o, já a analepse, analogamente, evoca ou narra um acontecimento anterior ao ponto da história em que se está.

Assim, analépticas são as pequenas narrativas como a do primeiro capítulo, que conta como Drogo tornou-se oficial, os anos de estudos, a renúncia e a reclusão na Academia Real, ou como a do capítulo XXVII que conta como ele se tornara um velho muito doente. As analepses podem surgir na narrativa após um salto temporal, como é o caso do capítulo XXVII, ou para esclarecer algo que acontecera antes do início da história, como acontece no capítulo I, tendo sempre como uma de suas funções primordiais completar informações, interar o leitor sobre eventos longínquos que se deram antes do início da fábula, mas importantes para a compreensão global da trama.

Pensemos, então, no maior salto temporal do Deserto que se encontra entre os capítulos XXIV e XXV, resta aí uma elipse de 15 anos a ser completada por esta narração analéptica:

A guardarsi attorno niente sembra mutato. Le montagne sono rimaste identiche, sui muri del Forte si vedono sempre le stesse macchie, ce ne sarà anche qualcuna di nuova, ma di dimensioni trascurabili. Uguale è il cielo, uguale il deserto dei Tartari se si eccettua quel palo nerastro sul ciglio del gradone e una striscia diritta, che si vede o non si vede secondo la luce, ed è la famosa strada.

Quindici anni per le montagne sono stati meno che nulla e anche ai bastioni del Forte non hanno fatto gran male. Ma per gli uomini sono 
stati un lungo cammino, sebbene non si capisca come siano passati tanto presto. Le facce sono sempre le stesse, pressapoco; le abitudini non sono mutate, né i turni di guardia, né i discorsi che gli ufficiali si fanno ogni sera. (p. 198-199).

O trecho aqui reportado demonstra com clareza a função de uma analepse, que é a de completar informações. A estrada do deserto demorou 15 anos para ser construída, mas seu processo não é relatado; ao fim do capítulo XXIV ela está se iniciando e, no incipit do XXV já está pronta, mas restam 15 anos para serem descritos por uma analepse que intera sobre fatos que em nada contribuem para o andamento da história, esta analepse informa aquilo que já sabíamos: o tempo, aprisionado pela rotina, parece não passar, mas a conclusão da estrada denuncia esta falácia.

Já as prolepses indicam um movimento inverso ao das analepses. Para Genette, a antecipação é menos freqüente na tradição narrativa ocidental, sobretudo na história do romance, por ir de encontro ao suspense narrativo. Sobre as prolepses em $\mathrm{Il}$ deserto dei Tartari nos debruçaremos mais adiante, em nosso segundo capítulo.

As anacronias, que têm suas funções bem definidas de antecipar um evento ou interar sobre o que já se passou, contribuem para a tessitura da intriga, porém não deve ser ignorado o fato de elas implicitamente aludirem ao ato de narrar, de engendrar os eventos em uma narrativa. Antecipações e recuos denunciam a verdadeira natureza da narrativa ficcional que é a de ser uma construção.

Já o aspecto da duração é para o teórico francês questão mais espinhosa do que confrontar a ordem (tal evento ocorreu antes ou depois de outro evento) e a freqüência (tal episódio aconteceu uma ou mais vezes) entre tempo da história e tempo da narrativa, pois não é possível postular uma "velocidade padrão" de leitura à qual confrontar os diversos tipos de duração narrativa. O "grau zero" de ordem entre história 
e narrativa, ele mesmo uma convenção, sequer existe em se tratando da duração; não há, pois, um ponto de referência estável para o confronto, ainda que de maneira altamente convencional a cena de um diálogo supõe uma espécie de igualdade entre os tempos da narrativa e da história. Porém uma comparação rigorosa desse aspecto é empresa de antemão irrealizável.

Velocidade é um valor que se obtém a partir de relações entre tempo e espaço, mas um texto pode no máximo ser medido em linhas ou páginas, já o ritmo de leitura, como discutimos anteriormente, é algo difícil de precisar. O que se mede, então, desse aspecto é a variação de velocidade entre os diversos segmentos diegéticos, já que uma constância é também e somente hipotética, consideram-se as acelerações e os retardamentos, uma questão, enfim, de efeitos de ritmo que têm referências aproximativas e não rigorosas. Os quatro principais movimentos de duração narrativa, cada um com seu ritmo próprio são a cena, a pausa, o sumário e a elipse.

A cena constitui-se como o movimento predominante em qualquer narrativa, definida como andamento ordinário da diegese em que, convencionalmente, tempo da história e tempo da narrativa se equiparam. Isto se dá, por exemplo, quando Drogo e Ortiz despedem-se para sempre um do outro no capítulo XXVI do Deserto. O embaraço do colóquio entre os dois oficiais que desperdiçaram toda uma vida a esperar nos muros da Bastiani, pontilhado de frases genéricas e vazias de sentido, pois o essencial é calado, explica-se pelo tremendo incomodo que o silêncio impõe aos dois homens, silêncio este extremamente significativo. É justamente o diálogo que confere a sensação, ainda que altamente convencional, de igualdade, ou ao menos de grande semelhança com o tempo empregado fora da ficção numa ação similar, contribuindo assim para instaurar o efeito de equivalência entre história e discurso. 
Já a pausa, que pode ser descritiva ou reflexiva, representa uma suspensão no andamento da diegese, desta forma, por maior que seja o tempo empregado numa descrição, a ação encontra-se como que congelada. Numa pausa, enquanto o discurso narrativo avança, o tempo da história permanece fixo no ponto em que fora deixado, nesse sentido, enquanto o narrador do Deserto imagina interessantes situações que podem ocorrer num espaço de tempo circunscrito em 22 meses (no início do capítulo V), como a construção de uma casa, os progressos motores e cognitivos de uma criança, o processo de cicatrização da dor de uma grande perda, nada acontece na diegese, Drogo continua a dormir inconsciente, não há movimento algum no andamento da história. Porém é evidente a importância da pausa na veiculação de sentidos que têm importância global na composição de qualquer trama narrativa.

O sumário é uma narração em algumas linhas, alguns parágrafos ou algumas páginas de vários dias, meses ou anos de existência, sem pormenores de ação ou de palavras, numa narração resumida em que vários eventos apresentam-se sobre a forma de tópicos. No sumário o tempo narrativo corre muito mais rápido do que o tempo da história, e o movimento sugerido é o da aceleração, como acontece já no primeiro capítulo do nosso romance:

Era quello il giorno atteso da anni, il principio della sua vera vita. Pensava alle giornate squallide all'Accademia militare, si ricordò delle amare sere di studio quando sentiva fuori nelle vie passare la gente libera e presumibilmente felice; delle sveglie invernali nei cameroni gelati, dove ristagnava l'incubo delle punizioni. Ricordò la pena di contare i giorni ad uno ad uno, che sembrava non finissero mai. (p. 3)

Em que grande parte da vida pregressa de Drogo é narrada em parte de um único parágrafo, em que se relata toda a luta e sacrifício do protagonista para chegar à posição em que se encontra no início da fábula. Obviamente o sumário contempla questões de 
economia narrativa, em que determinados episódios deixam de ser desenvolvidos e são apenas mencionados, seja por terem importância reduzida - o que configura o uso mais corriqueiro desse andamento narrativo-temporal —, ou, de maneira oposta, pincelar apenas eventos de importância capital e que, tiranicamente, têm seus desenvolvimentos negados ao leitor.

Finalmente, sob o aspecto da duração temporal em narrativa, Genette descreve a elipse, que consiste em saltos temporais na narrativa ou na omissão de acontecimentos de determinada porção de tempo da história, fazendo-se ou não menção a esse movimento. Na elipse, o tempo da história é que avança mais rapidamente que o da narrativa, a aceleração agora se encontra no campo oposto ao do sumário, ou seja, no tempo da história. A um salto temporal normalmente se encadeia uma narração analéptica, com a finalidade de cobrir o que fora deixado para trás, como no capítulo XXV do Deserto, que após o grande salto temporal de 15 anos, tempo gasto para construir a estrada na planície dos Tártaros, retrospectivamente se narra que a vida no Bastiani durante esse intervalo fora sempre igual. Em duas outras elipses nos capítulos seguintes Drogo é reduzido a um pobre velho enfermo, pois mais 14 anos são “engolidos” pela narração.

As relações de freqüência (ou simplesmente de repetição) entre história e narrativa formam um dos aspectos essenciais da temporalidade narrativa. Um evento pode, além de produzir-se, reproduzir-se e repetir-se. A repetição é, para Genette,

(...) uma construção do espírito, que elimina de cada ocorrência tudo o que lhe pertence em específico, para só conservar aquilo que partilha com todas as outras da mesma classe, e que é uma abstração. (GENETTE, 1979, p. 114). 
Trata-se, enfim da repetição de acontecimentos idênticos ou da recorrência do mesmo acontecimento, numa série de vários eventos semelhantes e apenas considerados em sua semelhança. Essa repetição é produto de uma abstração da consciência narrativa.

Sobre a relação de freqüência entre narrativa e história Genette esclarece de maneira simplificada que, numa narrativa pode-se “(...) contar uma vez o que se passou uma vez, $n$ vezes o que se passou $n$ vezes, $n$ vezes o que se passou uma vez, uma vez o que se passou $n$ vezes" (Ibidem, p. 114) [grifos do autor]. Assim, quando se conta uma vez aquilo que se passou uma vez enxerga-se nitidamente uma equivalência entre história e narrativa. Dentro da tradição narrativa é a forma mais recorrente e Genette propõe chamá-la de singulativa. Nesse sentido, uma cena singulativa é a narração de um evento que se deu uma vez no tempo da história e uma só vez é apresentado na narrativa.

Da mesma forma, contar várias vezes aquilo que se passou várias vezes é também narrar de maneira singulativa, pois o que importa aqui não é o numero de ocorrências e sim a igualdade entre narrativa e história. Já contar várias vezes aquilo que se passou uma só vez, com ou sem variantes estilísticas, é simplesmente descrito pelo teórico francês como narrativa repetitiva. Esta repetitividade, claro está, encontrase somente no âmbito da narrativa. Enfim, contar uma única vez — ou de uma só vez — aquilo que se passou várias vezes supõe um trabalho de abstração e de síntese, pois vários eventos idênticos ou similares na história encontram seu conjunto representado em um único relato na narrativa, trata-se, pois, da narrativa iterativa.

Tem importância fundamental na definição da freqüência de um episódio, ou seja, se é ele singular ou iterativo, o comportamento dos verbos, o qual discutiremos a 
seguir. Uma ação singular tende a ser narrada nos tempos perfeitos, expediente que coopera na construção do efeito de unicidade do evento, como o episódio da morte de Angustina, no capítulo XV do Deserto, acontecimento mais extraordinário de todo o romance, peripécia que chega à soleira da aventura, ainda que esta tenha ocorrido em uma missão burocrática.

Genette sustenta que nos eventos iterativos os tempos imperfeitos do verbo dão a entender que se trata de uma ação que se dá com certa freqüência, ações, enfim, repetitivas. No entanto, nas descrições do cotidiano da Bastiani, não somente os verbos nos tempos imperfeitos colaboram na veiculação desse sentido, como veremos no trecho a seguir:

Abitudine era diventato per lui il turno di guardia, che le prime volte pareva insopportabile peso; a poco a poco aveva imparato bene le regole, i modi di dire, le manie dei superiori, la topografia delle ridotte, i posti delle sentinelle, gli angoli dove non tirava vento, il linguaggio delle trombe.

Dalla padronanza del servizio ricavava uno speciale piacere, valutando la crescente stima dei soldati e dei sottufficiali; persino Tronk si era accorto come Drogo fosse serio e scrupoloso, gli si era quasi affezionato.

Abitudine erano diventati i colleghi, oramai li conosceva così bene che anche i più sottili loro sottintesi non lo trovavano impreparato; e per lungo tempo alla sera stavano a chiacchierare insieme dei fatti della città che per la lontananza acquistavano smisurato interesse. Abitudine la mensa buona e comoda, l'accogliente camino del ritrovo ufficiali, giorno e notte sempre acceso; la premura dell'attendente, un buon diavolo di nome Geronimo, che a poco a poco aveva imparato i suoi speciali desideri.

Abitudine le gite fatte ogni tanto con Morel al paese meno lontano: due ore abbondanti di cavallo attraverso una stretta valle che oramai aveva imparato a memoria, una locanda dove si vedeva finalmente qualche faccia nuova, si preparavano pranzi sontuosi e si udivano fresche risate di ragazze con cui si poteva fare l'amore. (p. 70-71) [grifos nossos].

Mas, como podemos observar, a reiteração do substantivo abitudine - e outros de campos semânticos afins, como regole, padronanza -, assim como outras palavras e 
construções sintáticas, têm também peso considerável nesse procedimento, pois dão consistência textual à idéia da rotina.

Este trecho nos chama à atenção também para o fato de que as categorias que até agora vimos como estanques devem, desejavelmente, serem vistas em conjunto. A descrição dos fatos que motivaram a permanência de Drogo após os primeiros quatro meses de serviço — do qual reportamos somente uma parte — é uma narrativa analéptica, pois trata de eventos já acontecidos — ou que vêm acontecendo — na vida do herói até aquele momento (capítulo X); essa descrição é feita de maneira sumária, pois os acontecimentos são citados como tópicos, mencionados apenas. O sumário está a serviço da economia narrativa, pois, a partir dele a trama deve seguir e esta forma é apta a preencher, com rápidas informações, o que acontecera até então. Por questões econômicas também já vimos que essas cenas são iterativas.

O épico sempre relata seus acontecimentos como inteiramente passados. Narrar no pretérito significa relatar uma ação transcorrida e, no sistema gramatical, situá-la nos tempos passados. Porém a narrativa épica relata coisas sobre um mundo criado, que tem seu principal valor no âmbito estético e as enunciações sobre este mundo não têm, a princípio, relação como os fatos da experiência exteriores a ele. Para Kadem Hamburger (1975), a função específica do pretérito no épico indica não uma ligação com o passado, mas o desligamento da ficção com o real. A ficção épica localiza-se num espaço intemporal. Para Paul Ricoeur (1995), não fosse a natureza imperfeita da linguagem, a narrativa teria tempos verbais próprios e não precisaria lançar mão das formas gramaticais do passado nos verbos, uma vez que sua significação original foi abolida. Contudo, o tempo da narrativa é predominantemente o do pretérito, o tempo adequado ao registro posterior, ao relato. Resta ainda o fato de que, ao utilizar-se também dos 
tempos verbais usados em outros códigos, a narrativa alcança a ilusão de realidade, procedimento que colabora na instauração da verossimilhança.

O verbo na narrativa de ficção exerce função diferente daquela que desempenha na gramática. Para Benedito Nunes, esses "tempos verbais situam o leitor ou o ouvinte no processo comunicacional da linguagem" (NUNES, 1995, p. 39). Para Nunes, o efeito de distanciamento que o uso do pretérito perfeito, do imperfeito e do pretérito-mais-queperfeito indica que se está narrando, orientando-nos no mundo narrado (organizado posteriormente pela linguagem), num mundo distante (espacial e, sobretudo, temporalmente).

É sobre este mundo espacialmente distante e temporalmente organizado (um mundo geometricamente configurado) que nos debruçaremos a seguir, em nosso próximo capítulo. 


\section{Capítulo 2}

\section{A ordenação da intriga}

"Matamos o tempo; o tempo nos enterra" (Machado de Assis, Memórias Póstumas de Brás Cubas) 


\section{A ordenação da intriga}

Neste capítulo estudaremos a disposição dos episódios acompanhando sua sucessão nos capítulos do romance e apontando, sempre que possível, para o intervalo temporal abrangido por cada um e para as distâncias temporais entre eles. Discutiremos também um aspecto genérico desta narrativa, qual seja, sua filiação ou não ao tropo do romance de aventuras. O tratamento dado à duração temporal, as variações entre eventos singulares e iterativos serão objeto de análise ainda na primeira seção deste capítulo. Na segunda seção abordaremos os diversos pontos que estruturam esta narrativa, como a linguagem e o estilo de Buzzati e elementos estritamente narrativos como as antecipações, as simetrias e os paralelos entre episódios, espaços e personagens.

\subsection{Disposição dos episódios}

Il deserto dei Tartari não apresenta grandes distorções entre tempo da história e sua transposição para o tempo da narrativa, sobretudo no que diz respeito à seqüência temporal dos eventos, pois os episódios da fábula e da trama seguem a mesma ordem cronológica, não havendo recurso ao suspense nem aos expedientes de uma construção que beire a acronia, como ocorre por exemplo em La Coscienza di Zeno de Italo Svevo. O Deserto, nas palavras de Giulio Carnazzi (2002) na introdução à edição I Meriadiani, constitui-se de "una struttura che riduce all'osso l'intreccio, proprio per evidenziare il valore della parabola". O que chama à atenção, porém, é a flagrante desproporção temporal do foco narrativo. 
Observemos, primeiro, como este romance apresenta-se macro-estruturalmente; narra-se uma fábula que dura cerca de trinta e quatro anos, cuja trama se desenvolve em trinta capítulos e os cinco primeiros anos ocupam os 24 capítulos iniciais, já o restante do tempo, quase 30 anos, é narrado nos últimos seis capítulos. Todos os capítulos possuem tamanhos semelhantes e esta divisão nos auxiliará a organizar a análise. Mas deixemos de lado, por enquanto, esta grande desproporção focal e observemos como os episódios dos primeiros cinco anos de história se sucedem temporalmente e suas localizações dentro dos capítulos.

No primeiro capítulo, Giovanni Drogo parte na primeira manhã da história rumo à Bastiani, para onde fora destinado. A narração recorda rapidamente a fria despedida da casa materna e os árduos anos de estudo na Academia Militar para se tornar um oficial. Defronte a um inquietante espelho, o jovem oficial sente uma inexplicável angústia diante da nova vida que está prestes a se iniciar. Acompanhado pelo amigo Francesco Vescovi no primeiro trecho da estrada, sente que seus cavalos apresentam marchas diferentes, percepção que intensifica a angústia e a ansiedade diante do futuro desconhecido. É curioso notar também como a fortaleza, uma vez iniciado o caminho, é apresentada como que apartada do consorte civil, localizada em um mundo-outro, pois é longínqua e ninguém sabe onde fica, nem mesmo um viajante da região. Drogo ilude-se de ter atingido sua meta ao alcançar uma construção em ruínas guardada por um soturno morcego e um sugestivo vagabundo, mas é só o primeiro de muitos enganos e, assim, as sombras da noite o alcançam ainda no caminho e ele adormece antes de chegar ao forte.

No capítulo e manhã seguintes o protagonista retoma a difícil e íngreme estrada, incrustada nas rochas de uma grande cadeia de montanhas, tudo ali lhe parece hostil — "Provò a chiamare ma gli echi gli respinsero la voce con timbro nemico" (p. 9). Observa 
depois que, do outro lado do desfiladeiro, há outra estrada e uma sombra lá se move, é o capitão Ortiz - "un uomo come lui finalmente" (p. 9), a quem saúda com ansiedade juvenil. As estradas se encontram e Drogo trava seu primeiro contato com o mundo da Fortaleza, e o capitão lhe explica a situação da Bastiani, como a localização absurda, a construção superada e sua importância secundária no contexto do Exército nacional; porém uma guarnição de fronteira sempre receberá atenções especiais, ainda que esta guarde o deserto nos confins do reino, por onde ninguém — os Tártaros provavelmente são uma lenda - nunca passou. Sob o vôo agourento de corvos, pássaros que ostentam a sinistra alegoria da hostilidade, os oficiais perfazem o último trecho até à Bastiani.

Recém chegado à fortaleza — capítulo III — sente no ar um inquietante clima de mistério - "Si udiva, al di là di certi muri, la lontana eco di una risata che sembrò a Drogo inverosimile" (p. 21), e um súbito desejo de voltar imediatamente à cidade o toma de assalto. Mas, apresentando-se ao enigmático major Matti, descobre nas entrelinhas que isto não seria possível, sendo então persuadido a esperar quatro meses e sair após uma inspeção médica regulamentar. Entrementes o fantástico clima da fortaleza começa a deitar seus encantos sobre o protagonista que sente uma inexplicável vontade de perscrutar o deserto, como se por ele fosse chamado em seus mais recônditos e primitivos instintos, no que é atendido, em segredo, por um colega, e de modo a admirar pela primeira vez parte da desértica planície.

Nos capítulos seguintes, vemos aquilo que Antonio Candido chamou de “tentativa de desincorporação da Fortaleza" (CANDIDO, 1990, p. 57), por parte do herói desse romance; segmento que vai do quarto até o nono capítulo. Em sua primeira noite na Bastiani (capítulo IV), Giovanni tem a medida de sua imensa solidão, quebrada regularmente pelo incômodo barulho da cisterna, indício do lento, mas infalível escorrer 
do tempo. Deparamo-nos ainda com escassas alusões ao tempo transcorrido, como o "duas noites depois" da partida da casa materna, no capítulo V, em que Drogo monta sua primeira guarda e depara-se com o extremo formalismo militaresco da Bastiani, não sem provar, ainda que inconscientemente, um misterioso fascínio (sobretudo pelas trombetas de prata e seus férricos sons que causam nele um estado de quase entorpecimento). Conhece também a emblemática figura do sargento Tronk, "vecchia creatura della fortezza" (p. 36), meticuloso cumpridor do rígido regulamento. É neste primeiro serviço de Drogo que o narrador nos revela, poeticamente, que "proprio quella notte cominciava per lui l'irreparabile fuga del tempo" (p. 46). Ainda na noite da primeira guarda, porém já no capítulo VI, tenta escrever uma carta a sua mãe, mas nem mesmo à ela consegue abrir verdadeiramente o coração e revelar sua imensa solidão e angústia, enquanto os gritos de "alerta" das sentinelas marcam o tempo que avança nesta noite. No sétimo capítulo, chega da cidade uma caixa com os pertences de Drogo. Da primeira oração do capítulo é possível inferir, com ajuda do advérbio, que há um intervalo de tempo considerável entre a primeira guarda e a vinda de seu "enxoval" militar, ou ao menos traduz o estado de ansiedade do protagonista: "Giunse finalmente dalla città la cassa con i vestiti del tenente Drogo" (p. 50) [grifo nosso], dentre eles um magnífico manto militar. Dirigindo-se ao alfaiate do regimento, sargento Prosdócimo, descobre o que motiva a permanência de tantos soldados naquela inóspita localização:

Dal deserto del nord doveva giungere la loro fortuna, l'avventura, l'ora miracolosa che almeno una volta tocca a ciascuno. Per questa eventualità vaga, che pareva farsi sempre più incerta col tempo, uomini fatti consumavano lassù la migliore parte della vita. (p. 55).

E Drogo, que lá deve restar apenas quatro meses, pensa poder assistir incólume à ânsia dos outros homens do forte que enxergam nessa fantasia, com aparência de realidade, a única possibilidade de justificar as próprias existências frustradas. No 
capítulo sucessivo vemos, numa noite chuvosa, o jantar de despedida de um colega, o tenente Max Lagorio. Salienta-se, porém, a imagem de seu amigo, o elegante, aristocrático e um tanto ausente, superiormente distante, tenente Pietro Angustina. Lagorio tenta em vão persuadir Angustina a também voltar para cidade, mas o que consegue é despertar nos outros ouvintes saudades do agradável consórcio citadino. Os amigos despedem-se na manhã seguinte.

No décimo capítulo, deparamo-nos com a chegada da neve e do inverno, indicando que mais uma boa porção de tempo se passou, mas a percepção de Drogo é outra:

"Mi sembra ieri che sono arrivato alla Fortezza" diceva Drogo, ed era proprio così. Sembrava ieri, eppure il tempo si era consumato lo stesso con il suo immobile ritmo, identico per tutti gli uomini, né più lento per chi è felice né più veloce per gli sventurati. (p. 64).

O jovem tenente desde cedo se deixa enredar pela uniformização que o tempo público e comum da Bastiani imprime à miríade dos outros tempos pessoais dos indivíduos, coletivizando experiências e homogeneizando expectativas. Drogo, ao se filiar ao tempo da fortaleza, negligencia sua própria temporalidade, a temporalidade pessoal que é constituinte da própria identidade.

Passado o natal e também o ano-novo, chega-se ao dia 10 de janeiro (evento datado com uma precisão incomum no Deserto), quando ocorre a inspeção médica prometida por Matti. O doutor Rovina, que de tudo já sabia, apronta os documentos do nosso herói que, pouco atento à pseudo-consulta perscruta, através da janela, a troca dos turnos de guarda sobre a neve e seu contrastante encanto, observa também detalhes da arquitetura da fortaleza que nunca dera atenção e, sob o lusco-fusco do poente, entra em 
um estado de verdadeiro torpor: os soldados, os sons das trombetas e a fantástica arquitetura da Bastiani anestesiam seus pensamentos, além do misterioso chamado da planície estéril que ressoa em seu interior e ele decide, para sua própria surpresa, ficar no forte.

No capítulo sucessivo, o narrador enumera as mesquinhas motivações da decisão de Drogo: a ordinária rotina da caserna, o fácil e estável serviço de guarda, as comodidades do quarto, da cozinha e etc. Até sermos surpreendidos por um "quase dois anos depois", no capítulo XI, fatia do tempo que na vida de Giovanni pouca ou nenhuma marca deixou: dias repetidamente idênticos dão a ilusão de que o tempo congelou-se. Nesse capítulo, narra-se um sonho de clima fabular, em que Drogo criança testemunha a morte de um colega, "pure lui bambino" (p. 80), o tenente Pietro Angustina. O tenente do perene ar de "distacco e di noia" (p. 80) começa a ganhar importância na trama, sobretudo ao se evidenciar seu caráter esnobe, distante, capaz de atitudes estoicamente altivas. Incomum é também o que lhe reserva o destino neste sonho: uma morte ímpar, gloriosa, fantástica.

No dia e capítulo seguintes ao sonho, narra-se como o desastrado soldado Lazzari é assassinado por descumprir ordens regulamentares. Comandando o Reduto Novo pela primeira vez, Drogo tem uma grande surpresa, já que algo se move no deserto em direção ao forte avançado. À alvorada descobre-se tratar de um cavalo inquietante sinal — indício de quiçá qual coisa maior. Ao descer à planície dos Tártaros e resgatar o cavalo que, como uma miragem, lá apareceu, o soldado Lazzari volta à Bastiani sem a senha de ingresso, falha que lhe custa a vida. O intransigente e implacável regulamento da fortaleza, verdadeira obra-prima barroca do brio militar, chega ao seu extremo: cumprindo-o à risca, a sentinela Martelli, por alcunha Moretto, 
passa de amigo a assassino, tendo Tronk como mentor do crime. Suas reações (estamos no capítulo XIII) comprovam a satisfação de quem enfim, testemunha "o triunfo do

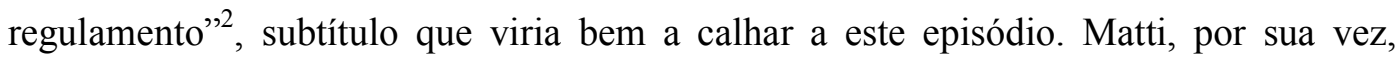
sente-se contente em ver que seus atiradores estão em forma, a ponto de não conseguir disfarçar sua insana alegria que é, antes do que absurda, coerente com a lógica da guarnição de fronteira.

Mas se um único disparo de fuzil já havia despertado o ânimo guerreiro entre os muros da Bastiani, o que dizer então de um tiro de canhão vindo do Reduto Novo, provavelmente no dia seguinte à morte do soldado, pois no capítulo XIV fileiras de soldados descem pela planície desértica rumo à Fortaleza e os soldados não têm dúvida de que a grande hora de suas vidas chegou, a batalha que justificará tanta espera e marcará para sempre de glória suas existências está prestes a começar, rompendo, enfim, uma imobilidade sem perspectivas. Neste ínterim titubeia apenas o comandante Filimore que, após longuíssimos anos de espera, não tem mais forças sequer para acreditar naquele robusto indício, na inegável virtualidade daquela ilusão, numa espécie de abúlico ceticismo. Porém, sua omissão o impede de cair em um equívoco, pois se descobre que os militares que vêm do norte não irão atacar, pois fazem parte de uma missão burocrática de demarcação fronteiriça.

Após a morte do soldado, é a vez de o tenente Angustina morrer efetivamente. Estamos mais ou menos no segundo ano da história, porém já nos encontramos na metade da narrativa, no capítulo XV. Chefiado pelo gigantesco capitão Monti, um grupo de soldados parte para um trecho das montanhas ainda sem demarcação, tendo por objetivo balizar os confins, antes dos soldados do norte, a fim de obter vantagem — não

\footnotetext{
${ }^{2}$ Il trionfo del regolamento é o título de um poema escrito por Buzzati em 1965.
} 
estratégica, mas sim moral —, visto que a localidade é completamente inócua. Da missão faz parte também o tenente Pietro Angustina, que a duras penas escala as montanhas, encontrando numa nevasca, ao entardecer, o fim de sua vida.

A "gloriosa" morte de Angustina tem importância capital na economia do romance, já que se trata de um evento com o qual o narrador teve extremo cuidado, salientando a figura do tenente em relação aos colegas, narrando com extrema elegância o sonho em que Drogo cede o papel de protagonista ao aristocrático oficial e exaltando sua figura como exemplo máximo almejado pela conduta militar na hora de sua morte. Angustina morre numa missão — uma paródia de combate — com extrema elegância e altivez. Comparado a São Sebastião, ganha status de mito, contudo, sua importância e sua morte não são apenas temáticas, mas também estruturais, como veremos adiante.

Alvaro Biondi, em seu artigo "Metafora e sogno: la narrativa di Buzzati fra 'Italia magica' e 'Surrealismo italiano'”, afirma que Il deserto dei Tartari é um "romanzo d'avventura svuotato" (BIONDI, 1992, p. 45), posição consoante com a de Pietro Pancrazi que, contemporaneamente ao lançamento do terceiro romance buzzatiano - Corriere della Sera, 2 de agosto de $1948^{3}$ - se perguntava: "Romanzo simbolico? romanzo satirico-umoristico? romanzo allegorico? romanzo surrealista? romanzo d'avventura, o almeno di quella rientrata avventura che spesso è la vita?" (PANCRAZI Apud BIONDI, 1992, p. 27-28). A ressalva de Pancrazi encontra um desenvolvimento em Biondi que sustenta que o Deserto apresenta todos os mecanismos de um romance de aventuras, no qual, porém, sempre falta um elemento essencial. A ausência de aventura afigura-se como um verdadeiro tropo da literatura italiana e vale mencionar aqui o ensaio "Mancata fortuna del romanzo italiano" de Italo Calvino que,

\footnotetext{
${ }^{3}$ Cfr. TOSCANI, 1987, p. 164.
} 
após repassar a obra dos grandes — mas tardios e de diversa substância — romancistas italianos (Manzoni, Nievo, Verga, Pirandello, Svevo etc.), conclui com irônica desolação:

Una cosa è sempre mancata al romanzo italiano, che mi è la più cara nelle letterature straniere: l'avventura. (...) come potrebbe darsi un romanzo d'avventura, oggi in Italia? Se lo sapessi, non starei qui a spiegarlo: lo scriverei. (CALVINO, 2003, p. 15).

O segmento que vai do XII ao XV capítulo é o mais movimentado do romance, mais rico em peripécias, porém, seus episódios encontram-se, por assim dizer, na antesala da aventura. A morte do soldado Lazzari, antes de um evento que movimenta a trama, é a simples execução de um procedimento prescrito pelo regulamento, uma ação, antes de tudo, burocrática. Assim como burocrática também era a missão dos soldados que marcham do norte rumo à Bastiani, mas a presumível invasão tinha escopos subjetivos demais para quem espera por uma batalha verdadeira, palpável, para quem busca sentir "l'acre e potente odore della battaglia" (p. 114). E se uma batalha real entanto não é possível, vê-se desta um arremedo. A ficção na paródia de combate em que morreu Angustina desdobra-se até o terceiro grau, num movimento em caracol: o duelo simulado de cartas alude à batalha sem armas de fogo e, em última instância, ao jogo ficcional de todo o romance.

Nesse romance de aventuras esvaziado, localizado num tempo e espaço de préaventura - ou ao menos a expectativa desta — ou, ainda, da pós-aventura, no qual justificar-se-ia a escolha do particípio passado (romance de aventuras esvaziado), num retrato de um mundo desolado, ou ainda aquele do cronotopo da não-aventura, onde a possibilidade de grandes peripécias, de uma prova qualificante, não se coloca. Um romance que espreita da soleira a aventura está a meio do caminho do processo histórico 
desse gênero descrito por Mendilow (1972), que desde as origens da ficção romanesca desemboca, contemporaneamente, no fim da importância da ação, deslocando o foco da atenção não mais para o enunciado e sim para a enunciação.

Apesar de semelhantes ao nosso, o tempo e o espaço retratados nessa narrativa são outros, um tempo e espaço outros que são pálidos e esguios reflexos da realidade que tomam como ponto de partida. Num romance de aventuras esvaziado, em um tempo e espaço outros - embora vagamente semelhantes ao tempo e ao espaço exteriores a essa narrativa - a realidade só pode ser a do sonho, a da letargia, a do entorpecimento dos sentidos, enfim, a realidade de um íncubo.

Mas voltemos aos episódios do romance. Após a seqüência de capítulos mais movimentada do romance, o tempo volta a se arrastar na fortaleza idêntico a antes, dias e noites se sucedem regularmente, assim como as estações, e Drogo já está na Bastiani há quatro anos (capítulo XVI). Em uma conversa numa tarde invernal com Ortiz agora major —, tendo por testemunhas novamente o vôo de corvos, é aconselhado a voltar à cidade e abandonar a fortaleza e a doentia esperança da vinda dos Tártaros. A primavera, quando menos se espera, chega surpreendendo os homens do forte (capítulo XVII), e os corações dos homens do forte começam a bater na expectativa de acontecimentos nada militares. Com a chegada da boa estação, Drogo tira uma licença e volta para sua cidade.

A licença de Drogo dura dois meses e sua volta para a cidade, narrada nos capítulos XVIII, XIX e XX, é apresentada como uma sucessão de fracassos e constatações de impossibilidades. Os quatro anos de caserna tiveram um alto custo para Giovanni e a vida presumivelmente fácil e leve da cidade já não mais lhe pertence. Os 
irmãos e os amigos estão longe e ocupados em outros afazeres, a mãe também tem sua vida social e nem o rumor de seus passos, ao voltar tarde de uma festa, podem mais acordá-la. Festa na qual não soube se divertir e o salão, pouco a pouco, se transformara na própria Bastiani.

Ainda na cidade, narra-se uma visita a Maria Vescovi (capítulo XIX), sua provável noiva, caracterizada por um diálogo que é mero festival de intenções recalcadas, formalidade e cordialidade extremas, pois o tempo e a distância interpuseram entre os dois um véu de separação, uma vez que mesmo durante a conversa as recordações do cotidiano da Bastiani não o abandonam e um inquietante feixe de luz solar marca o tempo da fatigosa conversa. Numa última - porém sem grande empenho - tentativa de fazer-se transferir para a cidade (capítulo XX), Giovanni Drogo passa por uma entrevista com um general no escritório do exército. Sob as nada auspiciosas energias de um dia chuvoso, a palestra é repleta de maus entendidos, como o fato de Drogo desconhecer uma nova norma regulamentar que exigia certa antecedência nos pedidos de transferência, além de o fato de Lazzari ter morrido sob seu comando ser outro empecilho, uma mácula em seu currículo.

Drogo, que tem as esperanças de deixar a Bastiani frustradas, é obrigado a lá voltar e restar quiçá por quanto mais tempo. Entrementes, encontra no forte renovado clima de ansiedade entre os soldados, excitados pela possibilidade de transferência, o que chega a inclusive estorvar o ritmo do serviço, outrora realizado tão zelosamente. No capítulo XXI, Giovanni assiste, a contragosto, à partida de vários oficiais no comando de inteiros pelotões, até mesmo a do tenente Morel, um seu amigo, assim a Bastiani diminui seu orgânico à metade e, após a partida do último grupo de soldados — capítulo XXII —, o tenente Simeoni tenta mostrar a Drogo, com sua luneta particular, algo que 
se move ao extremo norte do deserto. Ele acredita que se trate da construção de uma estrada com fins militares, tese que é recebida incredulamente por Giovanni Drogo e pelos demais homens do forte, mas a perene observação de Simeoni encontra, dia após dia, mais indícios de suas suspeitas - luzes noturnas, possíveis movimentos de uma infinitamente longínqua mancha negra. Empenhado em perscrutar o deserto com Simeoni, o inverno pega Drogo de surpresa: é o tempo que, impassível, continua a devorar os dias, mas ele, entorpecido pela observação do deserto, sugestionado pela clara luz das areias e pelo inexplicável chamado às experiências mais antigas da psique humana, como a travessia e o nomadismo, não é capaz de perceber esta fuga.

O incipit do vigésimo terceiro capítulo traz um ofício do comando superior proibindo o uso de instrumentos óticos privados e a divulgação de falsas suspeitas de agressões futuras provenientes do norte, ordem que Simeoni acata vilmente, apesar do tom genérico da circular e de suas verdadeiras crenças. "Il fiume del tempo", apesar de lento, não pára nunca e, quiçá quanto tempo depois, a luz do suposto canteiro pôde ser vista até pelas obsoletas lunetas da Bastiani, continuamente pelas sentinelas de visão privilegiadas, pelas pessoas de vista normal e a construção da estrada revela-se um fato inegável no capítulo XXIV.

Até este ponto passaram-se cerca de cinco anos (mas referências temporais dadas pelo narrador raramente são precisas) desde a chegada de Drogo à Bastiani, o tempo avançou, devorou dias, meses, estações, mas os homens do forte pouco ou nada notaram. Os dias que se repetem sempre iguais fazem tábula rasa da percepção dos soldados:

Di giorno in giorno Drogo sentiva aumentare questa misteriosa rovina, e invano cercava di trattenerla. Nella vita uniforme della Fortezza gli mancavano punti di riferimento e le ore gli sfuggivano di sotto prima 
che lui riuscisse a contarle. (p. 195).

Nestes primeiros vinte e quatro capítulos o tempo é manipulado pelo narrador de duas formas: uma linear, outra cíclica ${ }^{4}$. O tempo linear é o escorrer cronológico do tempo, marcado pelos eventos singulares, que nessa narrativa são raros, por isto é pouco percebido pelas personagens, já que o tempo cíclico, que aqui é representado pela monótona e repetitiva rotina militar, o escamoteia: a iteratividade do serviço esconde a linearidade do tempo, como as trocas de guarda, as paradas de ordem unida, os cantos das trombetas que marcam a regularidade da vida de caserna, bem sintetizada neste trecho:

Così la pianura rimase immobile, ferme le nebbie settentrionali, ferma la vita regolamentare della Fortezza, le sentinelle ripetevano sempre i medesimi passi da questo a quel punto del cammino di ronda, uguale il brodo della truppa, una giornata identica all'altra, ripetendosi all'infinito, come soldato che segni il passo. Eppure il tempo soffiava; senza curarsi degli uomini passava su e giù per il mondo mortificando le cose belle; e nessuno riusciva a sfuggirgli, nemmeno i bambini appena nati, ancora sprovvisti di nome. (p. 204).

As descrições destes ritos militares aludem à iteratividade destas ações e os homens da Bastiani estão sujeitos à rotina, algo que Bakhtin (1993) denominaria a pior das punições a que se pode condenar um personagem romanesco. Da rotina resulta a ilusão de tempo congelado, pois as geométricas regras militares são uma tentativa inconsciente - e inútil - de frear a inevitável e impiedosa passagem do tempo, identificada, no trecho supracitado, pela primeira vez com a morte. O Deserto, enquanto romance de aventuras esvaziado, está privado de ações ímpares, de eventos que movimentam a trama e que sempre marcaram o gênero épico. Il deserto dei Tartari é o romance da impossibilidade da aventura ou de ações heróicas e únicas, que fogem ao banal, já que aqui tem lugar o ordinário, o corriqueiro, o trivial; não o destino invejável

\footnotetext{
${ }^{4}$ Sobre este ponto conferir também CANDIDO, 1990; PANAFIEU, 1992 e BIONDI, 1992.
} 
dos grandes e imortais heróis, mas o destino médio, sem memória histórica e sem glória de cidadãos comuns. Mauro Maldonato, a respeito da busca pela própria identidade, sentencia: "O tempo da regularidade, a repetição opressiva da Ordem e da Lei, é um jogo insuportável que impossibilita qualquer conhecimento, reconhecimento de si mesmo, revelação de si mesmo" (MALDONATO, 2001, p. 115) [grifo do autor]. O estilo de vida da Bastiani condena seus homens a um exílio de si mesmos, a uma vil renúncia pela busca do conhecimento próprio, camuflados sob normas que nivelam tudo e todos, entrincheirados para esconder-se da vida numa construção inverossímil, seja pelas estruturas de sua edificação, seja por sua própria — imprecisa e inalcançável — localização.

Alguns estudiosos costumam tratar o problema dos tempos linear e cíclico usando as figuras da linha e do círculo, porém, na trama, há um exato momento em que estes dois elementos se cruzam, e isto é bem demarcado, como veremos a seguir, por um verbo no passado perfeito.

Se o ritmo do escorrer do tempo é em certos passos angustiante nos vinte e quatro capítulos iniciais, leiamos, então, o incipit do capítulo XXV:

Un palo è piantato sul ciglio del gradone che taglia longitudinalmente la pianura del nord, a neppure un chilometro di distanza dalla fortezza. Di là fino al cono roccioso della Ridotta Nuova il deserto si stende uniforme e compatto, così da permettere alle artiglierie di procedere liberamente. Un palo è confitto sull'orlo superiore dell'avvallamento, singolare segno umano, che si vede benissimo anche a occhio nudo dalla sommità della Ridotta Nuova.

Fin là sono arrivati gli stranieri con la loro strada. Il grande lavoro è finalmente compiuto, ma a che terribile prezzo! Il tenente Simeoni aveva fatto un preventivo, aveva detto sei mesi. Ma sei mesi non sono bastati per la costruzione, né sei mesi, né otto, né dieci. La strada è ormai finita, i convogli nemici possono scendere dal settentrione al galoppo serrato, per raggiungere le mura della Fortezza; dopo non resta che attraversare l'ultimo tratto, poche centinaia di metri su un terreno liscio ed agevole, ma tutto questo è costato caro. Quindici anni 
ci sono voluti, quindici lunghissimi anni che pure sono corsi via come un sogno. (p. 198).

Nesta passagem, a elipse temporal assemelha-se a um furto, pois o narrador "rouba" 15 anos de Drogo, de seus colegas, e também do leitor, escusando-se apenas por uma pequena narração retrospectiva na qual diz que durante esse período tudo foi igual como sempre, ou seja, que o tempo cíclico continuou a escamotear o escorrer do tempo linear, furto operado pelo domínio que a consciência narrativa tem daquilo que Benedito Nunes, inspirado em Thomas Mann chama de "feitiço hermético" (NUNES, 2000, p. 33-34), que é a refiguração, em termos narrativos, da experiência da temporalidade. E se o tempo de espera pelo fim da construção da estrada passou como num sonho, é porque Drogo é alguém que efetivamente teve a percepção alterada pela geometria da vida na Bastiani, não se dando conta sequer dos efeitos do tempo no espaço: uma mancha de mofo em um muro aqui, um ângulo de escada limado ali, um desmoronamento nas montanhas acolá... Nesta outra parte da trama, inaugurada pelo término da construção da estrada, o escorrer do tempo é vertiginoso, pois os seis últimos capítulos dão conta dos quase trinta anos restantes da história. Além do fim da construção da estrada militar através do deserto, podemos seguir os principais eventos dos últimos capítulos em sua sucessão cronológica.

Ainda no capítulo XXV, vemos que, não obstante a construção da estrada, o efetivo da Bastiani é mais uma vez diminuído e o agora capitão Drogo, "ancora una volta” (p. 200), retorna à fortaleza após uma licença (sabe-se lá quantas em todo o período, pois "una" é aqui um artigo indeterminado, não um numeral), na qual nos deparamos com a morte de sua mãe, a perene distância dos irmãos e amigos e seu incondicional apartamento do estilo de vida na cidade. Na estrada que leva ao forte, Drogo encontra um jovem tenente, Moro, recém destinado à Bastiani, encontro idêntico 
ao tido, mais de vinte anos antes, com o capitão Ortiz (capítulo II), mas agora os papéis estão invertidos. Neste preciso momento, a linha e o círculo se cruzam e Drogo finalmente pode ter a medida do tempo passado:

Solo allora lo colpì, con dolorosa risonanza dell'animo, il ricordo del lontanissimo giorno in cui per la prima volta egli era salito alla Fortezza, dell'incontro col capitano Ortiz, proprio nello stesso punto della valle; della sua ansia di parlare con una persona amica, dell'imbarazzante dialogo attraverso il burrone.

Esattamente come in quel giorno, pensò, con la differenza che le parti erano cambiate e adesso era lui, Drogo, il vecchio capitano che saliva per la centesima volta alla Fortezza Bastiani, mentre il tenente nuovo era un certo Moro, persona sconosciuta. Capì Drogo come un'intera generazione si fosse in quel frattempo esaurita, come lui fosse giunto ormai al di là del culmine della vita, dalla parte dei vecchi, dove in quel giorno remoto gli era parso si trovasse Ortiz. E a più di quarant'anni, senza aver fatto nulla di buono, senza figli, veramente solo nel mondo, Giovanni si guardava attorno sgomento, sentendo declinare il proprio destino. (p. 202) [grifos nossos].

Os verbos no perfeito salientam, quase dramaticamente, o peso deste episódio na vida de Drogo, além da escolha lexical do verbo colpire, que confere maior impacto à descrição da descoberta abrupta da fuga do tempo. Já o verbo capire tem, nesse trecho, um sentido de ironia amarga, pois se entende de uma só vez que a flor da idade há muito se passou e o que resta agora é um lugar marginal na vida. Estes verbos no perfeito sugerem uma co-presença, naquele exato momento, entre a narração e a história, dando, assim, maior expressividade a este fatídico evento.

Há um tempo difícil de precisar depois do término da construção da estrada, mas os cálculos nos levam a crer que estejamos quase no trigésimo ano de Drogo no forte (capítulo XXVI), o agora tenente-coronel Ortiz parte para a aposentadoria não sem antes incentivar, porém de maneira ambígua, Giovanni a restar ainda um pouco mais na Bastiani, pois ele era ainda jovem e ainda teria tempo para alcançar a grande guerra. A 
despedida entre os velhos oficiais é carregada de emoções não exprimidas, soterradas por um denso e significativo silêncio.

O capítulo seguinte nos surpreende ao apresentar o Major Drogo aos 54 anos, muito fraco, doente e debilitado, a quem agora finalmente pode-se chamar de velho. Como raramente sai de seu quarto, o costureiro Prosdocimo vai ao seu encontro para avisá-lo que os inimigos rasgam a estrada rumo à Bastiani, notícia que soa inverossímil: o clima instaurado pelas isotopias ${ }^{5}$ da espera saturou-se e o espanto, ao deparar-se com o evento mais esperado do romance — os tártaros chegam de surpresa —, é paradoxal. Às custas de muito esforço, sobrando dentro do uniforme, Drogo sobe ao terceiro reduto para observar com a antiga luneta de Simeoni - agora comandante da Bastiani — a descida dos soldados do norte; vilmente esperou não ver nada, mas a visão daquilo que o fez consumir toda a sua vida causa-lhe um dantesco desmaio ${ }^{6}$.

"Passarono un giorno e una notte" (p. 219), assim começa o vigésimo oitavo capítulo, em que Simeoni visita pessoalmente o enfermo major Giovanni Drogo, agora visto ironicamente como peso inoportuno na Bastiani quando os inimigos estão prestes a assaltá-la. Mortificado e sob ressentidos protestos — uma vida a esperar pelos Tártaros lhe dava o tácito direito de permanecer e guerrear, ou quem sabe apenas assistir à batalha — é mandado embora pelo insensível comandante. Para apanhá-lo vem uma magnífica carruagem para enfermos (capítulo XXIX), enquanto reforços chegam de

\footnotetext{
5 Entendemos aqui Isotopias no sentido greimasiano: recorrências lexicais, na superfície textual, de campos semânticos que colaboram na instauração de sentidos dentro da significação global de um texto. Assim, fazemos referências aqui às Isotopias aos campos semânticos da "espera", da "esperança" e campos semânticos afins. (Cfr. GREIMAS, 1976).

${ }^{6}$ Giorgio Cavallini, na sua obra Buzzati: il limite dell'ombra, atenta para um adjetivo presente no capítulo XXVII do Deserto: "orribile", que, segundo ele, é de ascendência dantesca (Canto V), porém, curiosamente, não faz menção ao desmaio de Drogo no mesmo capítulo, pelo menos não diretamente. (Cfr. CAVALLINI, 1997 p. 112).
} 
todos os lugares do reino. Descendo rumo à cidade, resolve pernoitar no meio do caminho, em uma pensão de beira de estrada.

Enfim, no último capítulo, em um fleumático anoitecer, Drogo encontra-se só, num quarto estranho. Giovanni Drogo percebe que é hora de enfrentar sua grande batalha, sua grande hora. Dá-se conta de ter esperado a vida toda pelo inimigo errado, mas ele ainda tem tempo para se redimir e encontrar, ainda que in hora mortis, o sentido de toda uma existência e enfrentar, quase estoicamente, a ironia de todo um destino: "La vita dunque si era risolta in una specie di scherzo" (p. 231). Perante a morte, sentimentos confusos e contrários aparecem, como medo e coragem, desolação e esperança. Giovanni recebe com presunçosa dignidade — talvez tão elegantemente quanto Angustina - a grande dama que o visita nesta noite:

La camera si è riempita di buio, solo con grande fatica si può distinguere il biancore del letto, e tutto il resto è nero.

Fra poco dovrebbe levarsi la luna.Farà in tempo, Drogo, a vederla o dovrà andarsene prima? La porta della camera palpita con uno scricchiolio leggero. Forse è un soffio di vento, un semplice risucchio d'aria di queste inquiete notti di primavera. Forse è invece lei che è entrata, con passo silenzioso, e adesso sta avvicinandosi alla poltrona di Drogo. Facendosi forza, Giovanni raddrizza un po' il busto, si assesta con una mano il colletto dell'uniforme, dà ancora uno sguardo fuori della finestra, una brevissima occhiata, per l'ultima sua porzione di stelle. Poi nel buio, benché nessuno lo veda, sorride. (p. 234).

Encontrando ao fim da extenuante luta interna contra o tempo, a morte, "horizonte secreto" (RICOEUR, 1995) de toda existência humana. 


\subsection{Arquitetura narrativa}

Como visto anteriormente, Il deserto dei Tartari configura-se como uma fábula de mais ou menos trinta e quatro anos contada em trinta capítulos - em que os primeiros cinco anos ocupam os 24 capítulos iniciais - e o restante do tempo (quase 30 anos) é narrado nos últimos seis capítulos. O que teria provocado tamanha desproporção do foco narrativo em relação ao tratamento temporal dado na primeira parte do romance (capítulos I - XXIV) para a segunda $(\mathrm{XXV}-\mathrm{XXX})^{7}$ ? A resposta talvez esteja na arquitetura narrativa. Vejamos agora o procedimento narrativo descrito por Gérrard Genette chamado prolepse. Para Grosser (1986), uma das prolepses mais famosas da literatura italiana está na obra-prima manzoniana I Promessi Sposi:

Va a dormire, povero Griso, che tu ne devi aver bisogno. Povero Griso! In faccende tutto il giorno, in faccende mezza la notte, senza contare il pericolo di cader sotto l'unghie de' villani, o di buscarti una taglia per rapto di donna honesta, per giunta di quelle che hai già addosso; e poi esser ricevuto in quella maniera! Ma! così pagano spesso gli uomini. Tu hai però potuto vedere, in questa circostanza, che qualche volta la giustizia, se non arriva alla prima, arriva, o presto o tardi anche in questo mondo. Va a dormire per ora: che un giorno avrai forse a somministrarcene un'altra prova, e più notabile di questa. (MANZONI, 1992, p. 167).

Nesta passagem o narrador, no início do romance, faz alusão a um ato futuro de uma personagem, o "fiel" Griso que, de fato, no capítulo XXXIII da obra de Manzoni, trai Don Rodrigo ao denunciá-lo porque este contraiu a peste ${ }^{8}$. A prolepse é um mecanismo narrativo operado por aquele que detêm o poder da enunciação, de uma consciência narrativa que conhece a fábula do princípio ao fím e pode, de acordo com

\footnotetext{
7 Antonio Candido, em "Quatro esperas" (1990), com outros objetivos, divide o romance em quatro seqüências: incorporação à Fortaleza (caps. I-X); primeiro jogo da esperança e da morte (caps XI-XV); tentativa de desincorporação (caps XVI-XXII); segundo jogo da esperança e da morte (caps XXIII-XXX). Outros estudiosos também adotaram outras divisões de caráter operatório, como, por exemplo, Alvaro Biondi (1992).

${ }^{8}$ Episódio que Buzzati parodiou mais tarde no conto "La peste motoria". In: Sessanta racconti, Milano, Mondadori, 1992. A primeira edição é de 1958.
} 
suas intenções, antecipar ou retardar a apresentação ou a menção a um evento. Uma prolepse pode antecipar fatos vindouros que, na narrativa, podem se encontrar numa ordem diversa à da história. No capítulo VI de Il deserto dei Tartari lemos a seguinte passagem:

Giovanni Drogo adesso dorme nell'interno della terza ridotta. Egli sogna e sorride. Per le ultime volte vengono a lui nella notte le dolci immagini di un mondo completamente felice. Guai se potesse vedere se stesso, come sarà un giorno, là dove la strada finisce, fermo sulla riva del mare di piombo, sotto un cielo grigio e uniforme, e intorno né una casa né un uomo né un albero, neanche un filo d'erba, tutto così da immemorabile tempo. (p. 48-49).

Antecipando, assim, a situação que culminará, 24 capítulos mais tarde, na morte de Giovanni Drogo, no fim do romance: "Eccolo ora sulla solitaria riva di un mare grigio e uniforme, e attorno né una casa né un albero né un uomo, tutto così da immemorabile tempo. (p. 231). Tanto a prolepse manzoniana quanto a buzzatiana são procedimentos de narradores que conhecem toda a fábula, e que têm uma intenção específica com este recurso. Para Genette, o uso de tal recurso, raro nas narrativas por ir de encontro à criação do suspense da narrativa, pressupõe "uma consciência temporal perfeitamente clara" (GENETTE, 1979, p. 77), algo diferente da chamada onisciência. Buzzati, neste sentido, quer já de início acabar com qualquer expectativa positiva em relação a seu protagonista. Importante notar as semelhanças temáticas entre essas duas prolepses, já que elas apontam para a inconsciência do porvir da parte de quem dorme em oposição à consciência de quem narra de olhos bem abertos, um no presente e outro no futuro, ou, melhor dizendo, um no tempo da história e outro no tempo da narrativa. Este é um primeiro diálogo que se pode apontar entre as duas grandes obras desses autores, lembremo-nos também do "addio Fortezza" de Drogo no capítulo XXIX, clara alusão ao "addio monti” de Lucia no quinto capítulo de I Promessi Sposi. 
O trabalho de minar previamente perspectivas positivas não é exclusividade das prolepses, pois outros traços na superfície textual do Deserto também corroboram para isso, como, por exemplo, quando Drogo se olha no espelho no primeiro dia da história sem sentir a alegria esperada, ou quando a caminho da Bastiani, seu cavalo marcha, simbolicamente, diferentemente do de Vescovi e assim por diante. Mauro Mignone (1981) em Anormalità e angoscia nella narrativa di Dino Buzzati, identifica palavraschave do estilo buzzatiano e propõe agrupá-las em quatro temas: a) palavras que indicam ambigüidade e mistério, b) palavras que indicam absurdo, anormalidades e imprevistos, c) que indicam sensações de angústia e de medo e, d) aquelas que apontam para uma tentativa ilusória de fugir da realidade, não sem um fundo irônico. Demonstrando de maneira clara que:

È con queste notturne presenze, con questi mostri allusivi e inquietanti con queste atmosfere rarafatte e spettrali, con questo linguaggio gravido di stupore e di suspense - ingredienti narrativi nuovi nella tradizione letteraria italiana - che Buzzati, filtrando il reale attraverso la camera oscura dell'inconscio, ci dà la sua fantasia della cronaca, la rivelazione surrealistica cioè di quel assurdo quotidiano che può, in un preciso momento, esplodere su ciascuno di noi con sinistre premonizioni e fenomeni ambigui e inesplicabili. (Ibidem, p. 57).

Exatamente como expõe Mignone, este trabalho estilístico é realizado sobretudo no âmbito da linguagem, pois há certas palavras (nomes: substantivos e adjetivos, advérbios e conjunções) pertencentes há um campo semântico particular que atuam no interior da sintaxe buzzatiana, produzindo, como efeito, um truncamento, uma letargia no ritmo das frases e nos sentidos dos enunciados.

Nesse sentido, observemos alguns trechos pinçados de um dos mais curiosos e importantes - episódios, localizado no capítulo X. Após decidir ficar na Bastiani além dos quatro primeiros meses previstos, Drogo monta guarda pela primeira vez no 
quarto reduto, usando, numa esplêndida noite de lua-cheia, seu belo manto vindo da cidade, assim, "Drogo rimase solo e si senti praticamente felice" (p. 74) [grifo nosso]. Em toda sua obra Buzzati usou com maestria os advérbios, e temos aqui um exemplo de um uso irônico desta palavra, já que um único advérbio, localizado no coração do período, envenena todo o seu restante significado, sugerindo que, nesse sentido, a felicidade de Drogo tem, no mínimo, algumas ressalvas. Durante o serviço observa mais detalhes da pitoresca construção do forte:

Le mura in quel punto seguivano il pendio del valico, formando una complicata scala di terrazze e ballatoi. Sotto di lui, nerissime contro la neve, Drogo vedeva, alla luce di luna, le successive sentinelle, i loro passi metodici facevano cric cric sullo strato gelato. (p. 75) [grifos nossos].

Deparando-se com uma Fortaleza de arquitetura estranha, labiríntica, cujo efeito em quem a vê é sempre confuso, negro e de mau agouro, ela lhe parecerá sempre hostil, não obstante passe ali uma inteira existência, e o que se passa entre seus muros parece ter um sentido inalcançável. Drogo, imbricando-se mais e mais no quimérico forte, depara-se com algo não-regulamentar:

La [sentinella] più vicina, in una sottostante terrazza, a una decina di metri, meno freddolosa delle altre, se ne stava immombile, con le spalle appoggiate a un muro e si sarebbe detto addormentata. Invece Drogo la udì canterellare una nenia con voce profonda. (p. 75) [grifos nossos].

E no sempre indesejado percurso descendente ouve uma canção de cunho deploratório, em seguida, "Pensando a questa strana cosa, poiché il soldato se ne stava sempre in attesa, Giovanni disse meccanicamente la parola d'ordine: «Miracolo». «Miseria » rispose la sentinella e rimise l'arma al piede" (p. 76) [grifos nossos]. Mas 
nada poderia ser mais estranho do que viria a seguir. $\mathrm{O}$ diálogo entre o oficial e o soldado, só aparentemente pró-forma, revela o sentido de todo o romance, alegoria da vida humana, e o resultado de uma doentia esperança em um milagre revela-se, ao fim, num mísero evento trivial.

Miséria sim, porém a partir deste momento dirigimo-nos à soleira de uma outra dimensão, pois a canção nada mais era que uma ilusão auditiva causada pelas águas de uma cascata distante que extraía notas pelo contato com as pedras e o vento, resultando no som de uma voz humana que se está sempre prestes captar o sentido, mas esbarra-se sempre na impossibilidade de compreendê-la. Em suma,

Non era dunque il soldato che canterellava, non un uomo sensibile al freddo, alle punizioni e all'amore, ma la montagna ostile. Che triste sbaglio, pensò Drogo, forse tutto è così, crediamo che attorno ci siano creature simili a noi e invece non c'è che gelo, pietre che parlano una lingua straniera, stiamo per salutare l'amico ma il braccio ricade inerte, il sorriso si spegne, perché ci accorgiamo di essere completamente soli. (p. 76) [Grifos nossos].

O encontro com o soldado tem muito mais um sentido de separação que de comunhão, demonstrando como a vida é, portanto, um inquietante engano, nossas volúveis ilusões revelam-se, cedo ou tarde, misérias inertes, estranhamos aquilo que sempre nos foi familiar e a esperança apaga-se quando se desvela a frieza do mundo que nos cerca e descobrimo-nos irremediavelmente sós nesse mundo estranho e hostil. Não há a possibilidade de uma salvação milagrosa. 
Porém não podemos deixar de mencionar a mais buzzatiana das palavras, a conjunção eppure ${ }^{9}$, usada pelo escritor italiano em toda sua obra como um elemento perfeito para truncar o ritmo da frase e envenenar seu sentido. No XVIII capítulo,

L'uscio di casa fu aperto e Drogo sentì subito l'antico odore domestico, come quando, bambino ritornava in città dopo i mesi di estate in villa. Era odore familiare ed amico, eppure, dopo tanto tempo, vi affiorava alcunché di meschino. (p. 149) [Grifo nosso].

Substantivos, adjetivos, advérbios, conjunções, enfim, signos que parecem ser frutos de uma evidente pesquisa estilística por palavras que dão às frases de Buzzati a cadência de uma marcha reticente, envenenada em seu núcleo, sabotada por seu próprio mentor. Nesse sentido Mignone afirma que,

E nel creare la tensione di minaccia, le presenze inquietanti sono molto spesso create con un tessuto linguistico che rivela la presenza di una ricerca formale che arriva a volte ad accostarsi a certe caratteristiche della prosa d'arte, sia per l'uso insistito della metafora e della trasposizione verbale sia anche per la ricerca della denotazione aggettivale in posizione rivelata. (MIGNONE, 1981, p. 88).

Tal afirmação é consoante com a posição de Marcello Carlino que, sobre o estilo de Buzzati, afirma: "è una lingua che, (...) adotta moduli stilistici da spenta prosa d'arte" (CARLINO, 1976 p. 74). Seja seu estilo resultado de intenso trabalho formal ou fruto tardio da prosa d'arte, inegável é o efeito que esses signos trazem para, primeiro, o ritmo da frase, estendendo continuamente seus sentidos para outros campos da linguagem, colabora na instauração de efeitos de sentido pretendidos pelo autor, como o clima de angústia e suspensão das esperanças que perpassam toda essa narrativa, elementos constituintes da prosa poética de Dino Buzzati.

\footnotetext{
${ }^{9}$ Presente, inclusive, no título de um dos contos da coletânea Il crollo della Baliverna: "Eppure battono alla porta".
} 
Voltando a tratar das prolepses temos, no capítulo XI, o sonho premonitório de Drogo que vê a morte de seu colega, tenente Pietro Angustina; prolepse construída por um recurso agora diferente, ou seja, um sonho fabular, expediente antigo e de grande tradição literária. Este capítulo, um dos mais belos do livro, é um verdadeiro parêntesis retórico dentro do romance, por apresentar imagens diferentes das que se vê no restante da obra, ou seja, figuras ásperas, cruas, desérticas e sombrias, como vimos há pouco. Já o ambiente do sonho é fluido, dotado daquela leveza defendida por Italo Calvino em suas Lições para o próximo milênio (CALVINO, 2002), em que a leveza das imagens e da sintaxe, aliada ao clima propiciado pela luz leve da lua, fazem desse trecho um dos mais belos escritos buzzatianos. É um sonho no qual o sentido é, a princípio, inefável, mas a premonição se confirma no capítulo em que se narra a morte real de Angustina, quando trechos do sonho são citados, entre parêntesis e em itálico (no capítulo XV), destacados e isolados nitidamente, para que a sutileza destas imagens não contamine a aridez do restante da narração. No Deserto, o tema da leveza tem seu lugar garantido, ou seja, isolada na moldura de um sonho e de um capítulo específico e dentro de parêntesis isoladores e de itálicos que servem de sinalizadores de alerta.

Enfim, a morte de Angustina narrada no capítulo XV é, em lato senso, outra prolepse que utiliza o procedimento do paralelismo entre as personagens Angustina e Drogo. Pietro Angustina tem importância fundamental na economia do romance, é o protagonista de três inteiros capítulos (VIII, XI e XV), ou seja, dez por cento do livro, seu caráter aristocrático, sua tez pálida, sua silhueta esguia e seu perene ar de "distacco e di noia", um distanciamento entediado, quase uma afetação, instauram uma clara oposição à natureza pequeno-burguesa de Giovanni Drogo que, assim como os outros, também invejava Angustina, porém Drogo era o único a intuir o motivo pelo qual Pietro causava tanto fascínio entre seus colegas. Num romance de aventura esvaziado, em que 
falta a prova qualificante, em que não se vê uma ação que valide a existência do herói e seu status como tal, Angustina é a única personagem a conseguir provar seu valor numa batalha, algo almejado por todos, ainda que esta tenha sido apenas um arremedo.

Resta esclarecer ainda que as antecipações na narrativa do Deserto não invalidam nossa afirmação de que o andamento dos tempos da história e da narrativa são praticamente idênticos, pois a prolepse do sexto capítulo não narra antecipadamente, apenas evoca - e de maneira não muito clara - a situação final do romance. O sonho de Drogo (cap. XI) e a morte de Angustina (cap. XV) não são propriamente prolepses típicas, são prolepses em largo sentido, abstrações do princípio original do funcionamento desse recurso narrativo.

O paralelo entre as mortes de Drogo e Angustina revela-se pela simetria entre os dois eventos no discurso romanesco. As simetrias são elementos importantíssimos, pontos estruturantes da arquitetura narrativa, como, por exemplo, entre os encontros na estrada - talvez a grande estrada da vida - entre o jovem Drogo e o capitão Ortiz no segundo capítulo e sua especular reprodução no capítulo XXV, entre o novato tenente Moro e o agora experiente capitão Drogo. Estranho evento do misterioso clima da Bastiani, mais um sinal ignorado pelo apático Drogo.

Se uns chegam, outros se vão da fortaleza para sempre. Na despedida entre os tenentes Max Lagorio e Pietro Angustina (capítulo VIII) aquele tinha a estranha - e certeira - sensação de nunca mais ver seu amigo; Morel e seu pelotão deixam permanentemente a Bastiani sem uma despedida pessoal, negada por despeito dos demais colegas (especialmente Drogo) que ficavam; Drogo conversa com Ortiz, talvez seu único e sincero amigo de caserna, pela última vez quando este é reformado e 
despede-se da Bastiani (capítulo XXVI). Por fim, Drogo moribundo rejeita uma suposta despedida de Simeoni, se bem que não possamos ignorar a presença de Moro, o que instaura um percurso absolutamente simétrico (e aritmeticamente progressivo) entre o trio Ortiz-Drogo-Moro. Estas disposições quiásmicas nos remetem à imagem do espelho, inquietante presença na vida de Drogo. É no espelho que ele procura, em vão, no início da história, a alegria esperada e no espelho vê, no final da vida, seu rosto amarelado e consumido, reflexos da verdadeira essência de seu coração e de sua consciência, imagens disfóricas que deveriam inspirar nele a busca pelo autoconhecimento sempre negada.

Drogo enxerga-se também, no capítulo XXIX, no rosto de um recém-nascido e imagina que uma cena semelhante tenha acontecido quando ele era um bebê, o que eleva as possibilidades simétricas ao infinito. Mais sutis são, porém, as relações entre ilusão auditiva da voz de uma cascata (capítulo X) e a repetição desta situação na cidade, em que Drogo confunde o som das rodas de uma carruagem com a voz materna (capítulo XVIII), pois a necessidade de encontrar uma voz amiga (e humana) depara-se com o vazio de seres inanimados, indiferentes à qualquer tentativa de contato. Passando da percepção auditiva para a visiva, temos os feixes de luz da sala da casa dos Vescovi, durante a palestra com Maria (capítulo XIX) e aquela de seu quarto na Bastiani (capítulo XXVIII). O movimento desses feixes marca no espaço a inexorável corrida do tempo. Nestas simetrias da percepção — ou da falha desta — percebemos também uma simétrica disposição entre a cidade e a fortaleza, ingênua tentativa da psique de Drogo de unir os dois mundos. Por fim, a "carruagem encantada" que veio apanhar Angustina no sonho de Drogo (capítulo XI) reaparece no fim do romance para buscar Drogo moribundo, uma magnífica carruagem para enfermos, que nos leva novamente à simetria das personagens Drogo-Angustina, como vermos a seguir. 
Angustina nos é apresentado pela primeira vez no capítulo VIII que narra o almoço de despedida de seu colega e amigo de infância, o tenente Max Lagorio. Já de início nos é revelado que Lagorio é um Conde, o que nos permite inferir que Angustina também possua um título de nobreza territorial e, o fato de ser amigo do Conde não é o único, já que Angustina é sempre descrito como pálido, portador de um perene ar de distacco e di noia. No paradigma caracterizador dessa personagem podemos destacar os adjetivos "leve, sutil, elegante, aristocrático, gentil, refinado, bem educado, inteligente, culto, digno de ser imitado, sapiente, modesto, prudente" etc. Mas também "amargo, irônico, melancólico, pálido" (sempre pálido, descorado, tendo inclusive seu uniforme descrito como desbotado, destaca-se dos demais, em consonância com o perfil esguio de sua personagem), às vezes esnobe, misterioso, insondável. Tem o hábito de alisar com dois dedos os bigodinhos, para que estes se levantem, é um pouco doente como alguns heróis do Oitocentos, e é elegante inclusive quando assolado por uma crise de tosse. Em suma, uma personagem anacrônica. Neste capítulo, em que o protagonista deveria ser o tenente Max Lagorio, Pietro Angustina rouba a cena pela primeira vez e o narrador instaura um jogo de oposições entre os dois amigos de longa data que, não obstante possuírem a mesma origem, são completamente diferentes. Lagorio é preterido e Angustina tem sua figura salientada.

No capítulo XI é finalmente assinalada a oposição entre Drogo e Angustina. No sonho premonitório, dentro do paradigma de caracterização desta personagem, vemos que seu castelo é riquíssimo, sutil e elegantemente ornado e o franzino Pietro dormia sob sedas e com um pijama ricamente enfeitado; levíssimas a flutuar com seus véus são também as "apariçõezinhas" que naquela noite vieram apanhar Angustina, assim como a carruagem, um espetáculo maravilhoso que sequer conseguiu tirar dele seu ar 
indiferente, como uma personagem fadada e preparada para acontecimentos grandiosos. Angustina é angustiado, mas também angustiante.

Finalmente no décimo quinto capítulo, ponto central para a economia do romance, narra-se a incursão nas montanhas e a morte de Angustina. A oposição agora é com Monti, comandante da missão, rude capitão que não gostava do tenente e aproveita o fato de este não estar devidamente calçado para transformar a missão num tormento para ele. Com sua malícia rude e humor grosseiro, alude sempre aos sapatos e ao presumível sofrimento de Angustina, mas este se mostra forte, acompanha a marcha e não deixa transparecer sua efetiva agonia.

O tenente articula-se num nível lingüístico diverso e superior daquele do capitão e, ao reagir às provocações de Monti, Angustina, com desprezo, frieza, e mordaz ironia, chega a inverter, às vezes, a hierarquia. Porém os soldados da Bastiani perdem a paródia de batalha e não há mais tempo para voltar, a neve cai e começa a preparar o estupendo cenário da morte de Angustina; o jogo fictício de cartas com Monti iconiza o caráter também fictício do embate com os do norte. Somente no momento de sua morte é que se revela que Angustina morava num castelo e seu caráter e natureza eram frutos de uma aristocrática origem. Angustina soube lograr uma morte gloriosa e invejável, seja em sonho, seja em vida, pois morreu no alto da cadeia de montanhas, sendo comparado a São Sebastião, alcançando o status de um mito, tornando-se mais uma das grandes lendas que povoam o imaginário da Bastiani.

Ainda sobre a arquitetura estrutural da narrativa do Deserto, constatamos que, ao transpor o tempo da história para o tempo da narrativa, o enunciador manipula o tempo de tal modo que um evento acontecido no segundo ano da fábula, portanto bem no 
início da história, surja, no discurso romanesco, exatamente na metade da narrativa, construindo-se, assim, uma prolepse perfeitamente arquitetada para instaurar um paralelo entre Angustina e Drogo, que têm seus maiores eventos, ou seja, suas mortes, narrados em perfeita simetria nos capítulos XV e XXX, respectivamente, trabalho de uma consciência narrativa, de um espírito organizador marcado por um pensamento geometrizante.

Angustina apresenta-se assim como uma espécie de duplo de Drogo, ou seja, o outro a quem devemos encontrar para conhecer a si próprio, base da busca pela própria identidade a partir do contato dialético com o diferente. Mas querer enxergar-se no outro não é suficiente, pois Angustina representa aquilo que Drogo almejava e não pôde realizar. O narrador instaura uma oposição entre o pequeno burguês Drogo (herói de um romance, não de uma epopéia) e o aristocrata Angustina, oposição tanto temática, quanto social e estrutural. Quando chega a sua vez, Drogo também enfrenta a morte tão bravamente quanto Angustina, embora numa planície, sem platéia. E há ainda um índice que une os dois eventos: no sonho de Drogo, por fim, Angustina tem sobre os lábios frios um sorriso, e Drogo, enquanto espera pela morte, sorri. Estes misteriosos sorrisos diante da morte podem marcar a coragem, uma espécie de estóica bravura dessas personagens ante o momento fatal, ainda que esta altivez tenha lugar num confronto fictício, como no caso de Angustina ou, como no caso de Drogo, que busca enfrentar a morte com altivez num desconhecido quarto de pensão, seja mera presunção. Este sorriso, talvez, represente apenas o alívio pelo fim da angustiosa espera, um prazer proporcionado por uma morte redentora. 


\section{Capítulo 3}

\section{Relações tempo-espaço-homem}

La vita fugge, et non s'arresta una hora, et la morte vien dietro a gran giornate, et le cose presenti et le passate mi dànno guerra, et le future anchora; (Francesco Petrarca, Canzoniere, 272) 


\section{Relações tempo-espaço-homem}

Nesta última seção estudaremos a relação do tempo com outros elementos nessa narrativa buzzatiana, desde a construção metafórica de imagens da sua passagem que o aproxima e lhe confere um aspecto quase espacial, até a relação mais tensa entre tempo e espaço, observando as marcas que a passagem daquele imprime neste e, finalmente, mas ainda dentro desta mesma noção, a relação entre o tempo e o homem, delineando também as inevitáveis marcas de sua passagem sobre as personagens. Incluem a última parte dessa seção algumas observações sobre a nomeação das personagens e um estudo particular sobre os efeitos da passagem do tempo no protagonista.

\subsection{Imagens do tempo}

Vimos, anteriormente, como se dá o trabalho de refiguração, em termos narrativos, da experiência da temporalidade em Il deserto dei Tartari. Observaremos agora a construção de imagens da passagem do tempo, com recurso ao uso de metáforas e outros expedientes, aproximando o tempo do espaço num percurso que tende à materialização do tempo, levando-o a uma dimensão espacial.

Para Fulvia Airoldi Namer e Ives Panafieu essas imagens

Costituiscono un'eccezionale intensificazione semantica, a metà strada tra la banalità quotidiana del reale e l'utilizzazione metaforica sistematica. Lo spazio è essenzialmente un mezzo di lettura dei punti di riferimenti temporali, una presa di coscienza dello sgretolamento delle durate esistenziali. (NAMER; PANAFIEU, 1992, p. 99). 
Vejamos quais são as principais dessas imagens, suas recorrências e o que nos sugerem enquanto núcleos interpretativos.

Observemos Drogo e seu cavalo, ainda no primeiro capítulo, no caminho rumo à Bastiani:

Egli continua a salire per arrivare alla Fortezza in giornata, ma più svelte di lui, dal fondo, dove romba il torrente, più svelte di lui salgono le ombre. A un certo punto esse si trovano proprio all'altezza di Drogo sul versante opposto della gola, sembrano per un momento rallentare la corsa, come per non scoraggiarlo, poi scivolano su per i greppi e i rocioni, il cavaliere è rimasto di sotto. (p. 6-7).

Estas sombras, que parecem assenhorear-se de tudo, marcam a inexorável marcha do sol rumo ao ocidente, como em um relógio solar de grandes dimensões. As sombras aqui assustam pelo tamanho e pela velocidade com que marcham, mas representam também aquilo que têm de mistério, de indefinido, da impossibilidade de se definir a fronteira entre a luz e aquilo que não é mais luz, embaralhando os sentidos. As sombras são, aliás, um dos signos mais caros à poética buzzatiana como vimos anteriormente em nosso comentário sobre sua escrita, sobretudo pela carga disfórica evocada por esta imagem, como a falta de luz, de conhecimento (ou conhecimento parcial, indireto), o mau agouro, a dúvida e, enfim, o medo. Essa "luz dissimulada" (MALDONATO, 2001) é a própria imagem das coisas, mas de uma maneira fugidia, irreal, mutante, uma espécie de segunda natureza das coisas, da qual é impossível fugir, pois ela sempre se impõe, assim como a morte.

Todavia, não somente elementos disfóricos sinalizam o escorrer do tempo, pois, em oposição às sombras, temos os vários feixes de luz solar presentes em quase todo o romance: 
Una striscia di sole risplendeva sul tappeto e un orologio camminava. (p. 154) [...] La striscia di sole, percorso tutto il tappeto, ora saliva progressivamente lungo gli intarsi di uno scrittoio. (p. 159) [...] Drogo vide risplendere sul pavimento di legno una bella striscia di sole e sentì venuta la primavera. (p. 211) [...] la striscia di sole sul pavimento andava spostandosi. (p. 212) [...] Già la striscia di sole sul pavimento aveva fatto ampio giro. (p. 219) [...] Intanto fissava la striscia di sole che stava salendo lungo la parete di legno allungandosi di sghembo. (p. 222).

Mas se a forma de relógio solar, ao contrário da sombra e das trevas, deixa margem a uma interpretação auspiciosa, sobretudo pela carga de sentido positivo que a luz evoca, como a divindade, o conhecimento, a fecundidade e a vida, seu significado, contudo, nada tem de animador, ainda que se trate de um admirável espetáculo. Cruel é seu significado para o protagonista, já que as luzes delineiam os momentos, os dias, meses e anos que o protagonista desperdiçou e tem a menos para viver. $\mathrm{O}$ tempo, o verdadeiro inimigo que nos leva à morte, engana também por meio de sutis e belos artifícios. No eterno jogo entre a vida e a morte, simbolizado pela luz e pela sombra, Drogo tem contra si ambos os elementos.

A principal destas imagens é a do "rio do tempo": "Il fiume del tempo passava sopra la Fortezza" (p. 78); "Fiume, che pare lento ma non si ferma mai" (p. 195). Imagem adequada aos enganos que o tempo é capaz de realizar, como a ilusão de calmaria transmitida por um rio caudaloso, quase imóvel em sua superfície, mas robusto e potente em suas profundezas, numa torrente que nunca cessa, alegoria da por vezes imperceptível marcha do tempo, da fluidez das formas, da corrente da vida em direção à morte, com sua sucessão de desejos, sentimentos e frustrações — representados pelos seus vários desvios —, símbolo, enfim, da precariedade da existência humana que se escoa como as águas de um rio. Imagem que possui também outras variantes:

Gli antichi amici di Drogo, sulla soglia della casa che si sono costruita, amano adesso soffermarsi a osservare, paghi della propria 
carriera, come corra il fiume della vita e nel turbine della moltitudine si divertono a distinguere i propri figli, incitandoli a fare presto, sopravanzare gli altri, arrivare per primi. (p. 209).

Neste caso, o rio agora é o cenário de uma competição chamada vida, prova que só pode ter lugar numa grande corredeira onde os menos aptos são deixados para trás. Se o engano, o embuste está presente na imagem do rio manso e caudaloso, na raia de corridas não há espaços para imagens oblíquas, pois nela vemos a aflição e o espanto causados num inepto, atônito diante da disputa na qual fora derrotado por ter se abstido de jogar. Seja num rio grande e sereno, seja no frenesi de uma corredeira, a vida segue seu curso até o momento final, nunca deixando de cobrar o preço por essa grande e sinuosa viagem.

Já no capítulo XXVI o tempo sopra como o vento:

Eppure il tempo soffiava; senza curarsi degli uomini passava su e giù per il mondo mortificando le cose belle; e nessuno riusciva a sfuggirgli, nemmeno i bambini appena nati, ancora sprovvisti di nome. (p. 204).

Mas o movimento sugerido pelo sopro do vento, sempre instável e inconstante, antes de um refrigério para a alma, como mensageiro do divino, é sempre o de um avanço inelutável, seja ele violento ou aprazível, alivie com terna doçura o calor ou traga a cega e colérica tempestade. Aqui o tempo pela primeira vez é identificado com a morte, o vento é apenas seu mensageiro, indicando que por trás dos seus enganos está ela, inexorável e sempre à espreita.

Nos últimos parágrafos do sexto capítulo, enquanto Drogo dorme inconsciente no terceiro reduto, o narrador, por meio de uma espécie de parábola, condensa os significados mais profundos desse romance alegórico: 
Fino allora egli era avanzato per la spienserata età della prima giovinezza, una strada che da bambini sembra infinita, dove gli anni scorrono lenti e con passo lieve, così che nessuno nota la loro partenza. Si cammina placidamente guardandosi con curiosità attorno, non c'è proprio bisogno di affrettarsi, nessuno preme di dietro e nessuno ci aspetta, anche i compagni procedono senza pensieri, fermandosi spesso a scherzare. Dalle case, sulle porte, la gente grande saluta benigna, e fa cenno indicando l'orizzonte con sorrisi di intesa; (, p. 46-47).

Uma concepção fabular da "grande estrada da vida", o caminho a trilhar e o rumo que se dá à vida, com seus sucessos, fracassos, pausas, acelerações, perdas, enfim, nossa grande viagem, expressão da transitoriedade da vida humana. Mas depois da infância a estrada que parece infinita perde seu ar familiar e o tempo começa a correr espantosamente, provocando o medo de que não se possa realizar a tempo os sonhos da tenra idade, e depois que o "grande portão" se fecha às nossas costas, não se pode mais esperar a indulgência alheia: "Non più alle finestre si affacceranno ridenti figure, ma volti immobili e indifferenti” (p. 48). E quando menos se espera a marcha acaba, às margens de um mar de chumbo, sob um céu cinza, numa eterna desolação.

Estas imagens - o curso do rio, o movimento do vento e a grande estrada seguem um percurso que tende a uma gradativa espacialização do tempo, dando contornos materiais e palpáveis a algo que, mesmo em última instância é abstrato, recurso que torna visível o que é invisível, dá forma ao que é informe, conferindo continuidade ao que é descontínuo, transformando o tempo em seu contrário, culminando com a identificação tempo-estrada, que é seu ápice. Tempo e espaço encontram-se aqui numa relação de simbiose, confundindo-se até transporem os limites da parábola materializando-se na vida de Drogo:

L'amico Francesco Vescovi lo accompagnò a cavallo per il primo tratto di strada. Lo scalpitio delle bestie risuonava nelle strade deserte. Albeggiava, la città era ancora immersa nel sonno, qua e là agli ultimi piani qualche persiana si apriva, comparivano facce 
stanche, apatici occhi fissavano per un momento la nascita meravigliosa del sole. (p. 4) [grifos nossos].

Vescovi então já é um dos últimos companheiros no caminho de Drogo e os espectadores são a eles indiferentes, pois a via de retorno provavelmente já se encontrava bloqueada. Da composição dessa parábola, em que a relação tempo e espaço é a de imbricação e "une-identificação" que forma uma só figura, uma coisa só. "Uneidentificação" é o que sugere este trecho também entre a estrada da parábola e àquela que leva à Bastiani, último reduto da vida de Drogo. Porém, passaremos agora para uma relação de outra ordem entre tempo e espaço, em que trataremos da ação ativa de um sobre a inércia do outro.

\subsection{Tempo no espaço}

A “estrada da vida" representa a máxima identificação tempo-espaço, sugerindo até certa homogeneidade entre os dois termos, porém uma outra relação tempo-espaço institui-se nas marcas que a passagem do tempo imprime nos corpos físicos, oferecendo-nos uma possibilidade de leitura indicial desses eventos. O tempo precisa de corpos físicos para se exteriorizar, esta é a conclusão de Paul Ricoeur em seus estudos sobre a Recherche proustiana (RICOEUR, 1997). Para Namer e Panafieu, "oltre all'insistenza sull'immobilità, sulla staticità del tempo, è ugualmente possibile rilevare nel Deserto gli elementi di una fenomenologia spaziale del fluire del tempo" (NAMER; PANAFIEU, 1992, p. 101-102). Na superfície textual de Il deserto dei Tartari encontram-se diversas imagens que explicitam ou sugerem este aspecto: 
Il fiume del tempo passava sopra la Fortezza, screpolava le mura, trascinava in basso polvere e frammenti di pietra, limava gli scalini e le catene. (p. 78) [...] Il loro [das muralhas] aspetto nudo, le strisce nerastre degli scoli, gli spigoli obliqui dei bastioni, il loro colore giallo. (p. 145) [...] già qualche merlatura era caduta e un terrapieno si sfasciava in frana senza che nessuno lo facesse aggiustare. (p. 169).

A passagem do "rio do tempo" deixa, inevitavelmente, suas marcas pelo espaço, pois as dependências da Bastiani, que um dia foram novas em folha (quiçá quando), perdem, pouco a pouco, as características de obra recém-acabada apresentando, por exemplo, o amarelado dos muros que provavelmente não são sua cor original. Além deste, outros indícios como as manchas de limo, decorrência do derretimento das neves invernais, que crescem ano a ano; o lento processo de limagem das escadas e a degradação dos muros - e a poeira deles resultantes — são também inegáveis produtos da ação do tempo sobre o espaço, o qual, em termos narrativos, trata-se sempre de um espaço virtual criado pela linguagem, ganhando maior consistência em procedimentos como a utilização de dêiticos, conforme se lê no excerto abaixo:

Drogo guardava sulla polvere della strada l'ombra netta dei due cavalli, le teste che facevano sì sì ad ogni passo; sentiva il loro quadruplice scalpitio, qualche ronzare di moscone e niente altro. La fine della strada non si vedeva. Ogni tanto, ad una curva della valle, si scorgeva di fronte, altissima, tagliata in coste precipitose, la via che si arrampicava a zig zag. Ci si arrivava, si guardava allora in su, eccola ancora di fronte, la strada, sempre più alta. (p. 13) [grifo nosso].

O uso do dêitico nesse trecho delineia a estrada com contornos reais e quase visíveis, conferindo-lhe status de coisa palpável e acessível aos nossos sentidos, delineando na superfície textual a materialidade do objeto referido. O espaço ficcional é resultante de uma linguagem espacial.

Quando o forte tem seu efetivo reduzido à metade, atentamos para um curioso fato: 
Per la prima volta da quando era stata costruita la Fortezza alcuni locali vennero chiusi e sprangati. Il sarto Prosdocimo dovette liberarsi di tre aiutanti, perché non gli era rimasto abbastanza lavoro. Ogni tanto capitava di entrare in cameroni o uffici completamente vuoti, con sui muri le macchie bianche dei mobili e dei quadri portati via. ( $\mathrm{p}$. 180).

O fechamento de algumas dependências, outrora úteis e freqüentadas, as bloqueia, por assim dizer, da torrente do tempo, isolando-as do convívio e da dinâmica do serviço que também é afetado pela diminuição do orgânico. As manchas brancas nas paredes deixadas pelos móveis e quadros retirados são portadoras de inquietantes mensagens sobre passagem do tempo, verdadeiros rastros do passado, pois, ao contrário de um muro que se amarela aos poucos ou uma mancha de limo que cresce cotidianamente, esses testemunhos de uma ausência oferecem a possibilidade de leitura pontual do trabalho do tempo, algo que outrora tais objetos escondiam e agora oferecem a possibilidade de leitura pelo vazio.

Uma possibilidade de leitura semelhante encontra-se no capítulo XXVII, em que "le panchine di legno scolorito" (p. 212) são testemunhas imóveis e indefesas do poder de degradação do tempo, ruínas "históricas" que representam os movimentos dialeticamente opostos da ação corrosiva dos anos e da inação dos negligentes homens da fortaleza. Mas estes vestígios da passagem temporal, além de meios de leitura são também sinalizadores de alerta do poder de aniquilamento que o tempo traz consigo, algo que, no entanto, não são reconhecidos pelos soldados como tal.

Pouco antes de sua primeira licença, Drogo passeia a esmo pelas dependências do forte: "L'ufficiale si ferma guardando in su, a una delle alte finestre. I vetri sono chiusi, da molti anni probabilmente non sono stati lavati e negli angoli pendono ragnatele” (p. 145). As janelas emperradas testemunham o longo tempo passado, 
destarte também as teias de aranha, estabelecendo-se como meios de leitura da dinâmica entre tempo e espaço, símbolos do longo e paciencioso trabalho do tempo que atesta seu poder criativo, simbolizado pela teia de aranha, como também seu poder de estiolamento, representado pela ferrugem que emperra os mecanismos metálicos. Ainda neste episódio vemos que "Attraverso la polverosa finestra del lavatoio, per quanto possa sembrare strano, si riesce a vedere anche una nuvola bianca di forma piacevole" (p. 146), e a poeira, símbolo de morte e de luto, surge mais uma vez como subproduto da ação temporal e do abandono, entrecortando a visão através das janelas, outro símbolo que, nesse trecho, sofre em suas caracterizações um processo de degradação, pois, inicialmente, descreve-se como não lavadas e cheias de teias de aranha, num segundo momento como empoeiradas e, finalmente, são descritas como imundas.

As janelas, como bem demonstrou Walter Geerts no artigo "Forme, spazio, visione" (GEERTS, 1982), são signos importantíssimos nessa narrativa. Enquanto elementos de contato com o mundo exterior representam um meio oblíquo de observação, consoante com o clima de ambigüidade e de mistério do Deserto. É através de janelas, fendas nos muros ou mesmo de lunetas que se perscruta a realidade, de modo que estes elementos representam uma maneira indireta e parcial de percepção. Geerts relembra que no capítulo IV Drogo, na primeira noite em seu quarto, observa, pelo reflexo de uma janela no muro em frente, a sombra de outro oficial a se despir, sintomática iconização das limitadas possibilidades perceptivas do protagonista, o qual pode apenas visualizar os contornos e os perfis de uma figura no limite de uma penumbra, pois, nesse sentido, sua visão é invariavelmente mediada, oblíqua e indireta, seja pela janela, pelo reflexo ou pela sombra, resultando numa observação distanciada de vários graus da realidade. Como os prisioneiros da caverna de Platão que não têm acesso ao mundo ao seu redor e têm da realidade uma visão severamente comprometida, 
Drogo não conhece sequer a edificação na qual está encerrado. Da Bastiani, ínfimo ponto no vasto mundo, lugar onde homens renunciam à própria vida, ele pode aspirar conhecer apenas seu reflexo indireto, condição que o levará insciente à ruína.

Pode-se pensar que como no Mito da Caverna de Platão, em que impera o medo e a ignorância da verdade, Il deserto dei Tartari é em sua totalidade uma alegoria da precariedade da condição humana e da limitação de nosso conhecimento. O episódio do reflexo na parede oposta mostra, dentro da diegese, como o conhecimento de Drogo é ínfimo e talvez possa ser visto como uma antecipação de sua conduta futura, já que o oficial se manterá limitado às sombras e à inação durante todo o romance, até sua morte.

Geerts ainda chama a atenção para as restrições geométricas das visões mediadas, como o quadrado da janela, as diversas frestas nos muros, o círculo da luneta, ou o triangulo de deserto visível do terceiro reduto. No Deserto, a visão é sempre mediada ou oblíqua e a alçada da percepção é previamente limitada, quando não distorcida. Mas em se tratando de uma fortaleza fronteiriça, em que as regras e a disciplina são levadas às últimas conseqüências, o papel de tais restrições geométricas é o de inibir olhares mais atentos, pois, para a lógica militar uma visão aberta é extremamente nociva ao bom andamento do serviço.

Todavia, a mais robusta das provas da ação do tempo no espaço são os inúmeros desabamentos de rochas na cadeia de montanhas onde se situa a Bastiani:

Un marzo freddo e piovoso, accompagnato da smisurate frane sulle montagne; interi pinnacoli crollavano improvvisamente, per sconosciuti motivi, sfracellandosi negli abissi, e lugubri voci ritronavano nella notte anche per ore e ore. (p. 211). 
Mas antes de falarmos especificamente dos desmoronamentos nas montanhas, atentemos para o fato de que o tempo é paciente, trabalha suas marcas no espaço com extrema morosidade, a ponto de sequer serem, a princípio, notadas. Junte-se a isso a habilidade humana de habituar-se a pequenas mudanças. Dessa forma, o processo que leva uma parede branca ao cabo de vários anos a tornar-se amarelada é passível de não ser percebido por olhos que vêm esta parede quotidianamente e, ainda nesse mesmo sentido, nosso precário tato é insuficiente para se dar conta da limagem de escadas que são levadas a termo de incontáveis anos. Merleau-Ponty, em sua Fenomenologia da percepção, demonstra como os sentidos humanos são capazes de se adaptar, em pouquíssimo tempo, às mais bruscas mudanças espaço-visuais ${ }^{10}$ (MERLEAU-PONTY, 1994). As modificações nas dependências da Bastiani são quase insignificantes e somente um olhar de fora, de outra perspectiva, estranho à vida do forte, seria capaz de decifrar a mensagem deixada pelo tempo no espaço. Porém o ruir das rochas é apreendido pelos homens do forte apenas no fugaz momento da conclusão de um trabalho paciente e milenar do tempo, realizado ciclicamente pelo sol, pela chuva, pela neve e seu derretimento durante incontáveis anos.

O monótono ritmo de vida na Bastiani acaba por nivelar tudo ao seu redor. O tempo cíclico reduz a uma mesma condição ordens de natureza diversa como as montanhas, os muros e os próprios homens, fundindo-os em uma única massa amorfa e embaçada. Na infrutífera tentativa de dominar o tempo, o espaço e a natureza, o homem termina sendo por eles engolido, tornando-se imóvel e estéril como as rochas, ordenado porém inútil como as muralhas que defendem apenas da expectativa da ação e da aventura.

\footnotetext{
${ }^{10}$ Merleau-Ponty Cita, por exemplo, as experiências de Stratton que comprovam que o homem, após começar a enxergar o mundo de uma hora para a outra de cabeça para baixo, adapta-se a esta situação em menos de uma semana. (Cfr. MERLEAU-PONTY, 1994, p. 327 et seq.).
} 
Resta ainda considerar que o espaço não é somente uma chave de leitura da passagem temporal, pois a relação entre esses dois termos é ainda mais imbricada, como sugere Maldonato: "o espaço é a forma visível do tempo e o tempo, a forma visível do espaço; ou ainda, sem mudar a essência: o espaço dá forma ao tempo e o tempo, ao espaço" (MALDONATO, 2001, p. 136) [grifos do autor]. Como na identificação unitária na parábola da "estrada da vida", tempo e espaço são aspectos de uma mesma e indissociável realidade.

Perto do desfecho, o costureiro Prosdocimo é o primeiro a avisar Drogo de que os estrangeiros finalmente descem a estrada do deserto, ele enverga "uno strano vestito che un giorno doveva essere stato una uniforme da maresciallo" (p. 213), desalinho que evidencia o tempo passado. Além de encontrar-se todo curvado pela velhice, algo do qual não poderia fugir, é estranho notar como o chefe dos costureiros, além de não ter avançado na hierarquia militar, permita tamanha degradação em seu uniforme. Recuando-se aos primeiros anos da história, contudo, encontramos indícios sutis da ação do tempo também nos uniformes de Ortiz — "La sua uniforme era di linee rozze ma perfettamente in ordine" (p. 11) e de Angustina, com "sua uniforme azurra, stinta dal sole" (p. 58). Mas a principal marca da passagem do tempo nos uniformes encontrase nas patentes, como veremos adiante. 


\subsection{O tempo e as personagens}

Antes de tratarmos especificamente dos efeitos do tempo sobre as personagens vale a pena fazer algumas observações sobre a nomeação delas. A propósito Antonio Candido desenvolve um interessante estudo, no qual observa:

O nome dela [da Fortaleza] é em italiano, e quanto aos sobrenomes das pessoas, alguns poucos são usuais nesta língua, como Martini, Pietri, Lazzari, Matti, Santi, Moro. Mas há preferência pelos menos freqüentes como Lagòrio, Andronico, Consalvi; ou raros, como Batta, Prosdoscimo, Stizione, e pelos que parecem inventados a partir de outros nomes, como Drogo, de Drago; Fonzaso, de Fonso ou Fonsato; Angustina, de Agostinho; Stazzi, de Stasi. Significativo é o caso da derivação que leva o nome italiano para outras línguas, como Morel (francês), que pode ter Morelli como ponto de partida; ou Espina (espanhol), parecido com Spina; ou Magnus (forma latina ao gosto da onomástica alemã), com Magno ou Magni. No limite, os puramente estrangeiros: Fernandez, Ortiz, Zimmermann, Tronk, enquanto o do comandante Filimore, parece não pertencer à língua nenhuma. Esse jogo antroponímico contribui para dissolver a identidade possível do vago universo onde se situa a Fortaleza. (CANDIDO, 1990 p. 65-66).

O estudo de Candido busca revelar como o jogo heterogêneo da nomeação dos

homens da fortaleza coopera na instauração de um clima de suspensão nessa fábula, localizada em um tempo-espaço outro, semelhante ao nosso, mas de incerta ou inexistente filiação, infectado por uma vaga atmosfera entorpecida e embaçada. Essas observações do crítico brasileiro em muito diferem do que a Fortuna Crítica do Deserto desenvolve tradicionalmente, o que as tornam muito originais.

Sobre o batismo de personagens leiamos as palavras — ou testemunho — de um mestre nessa arte, Italo Calvino:

Io credo che i nomi dei personaggi siano molto importanti. Quando, scrivendo, devo introdurre un personaggio nuovo, e ho già chiarissimo in testa come sarà questo personaggio, mi fermo a cercare alle volte anche per delle mezzore, e finché non ho trovato un nome che sia il 
vero, l'unico nome di quel personaggio, non riesco ad andare avanti. (CALVINO, 2003, p. 8).

Imperativo ou necessidade já há muito tempo sintetizado pela máxima de Justiniano, nomina sunt consequentia rerum. É esta tradição que nos convida a estudarmos a onomástica de Il deserto dei Tartari.

A Fortaleza Bastiani é o lugar para os que têm, aparentemente, um firme propósito, lugar dos bravos bastiões do reino, mas também um lugar de martírio, de renúncia voluntária à vida. A primeira pessoa com quem Drogo tem contato na Fortaleza é o major Matti ${ }^{11}$, nome que expõe abertamente seu caráter, pois, não por acaso, é este mesmo major que se sente orgulhoso ao ver que um seu ex-aluno de tiro possua uma admirável mira, ainda que provada no insano assassínio burocrático de um colega. O médico do regimento também possui um sobrenome bastante insinuante, Rovina $^{12}$, sugestão nada auspiciosa para Drogo, mais uma antecipação do infortunado destino do protagonista.

A nomeação do meticuloso sargento Tronk, um nome quase onomatopaico, sugere a dureza e a força do frio especialista do regulamento, mentor da morte do soldado Lazzari e que exulta consigo mesmo o fato de as normas terem prevalecido sobre aquele que as quis burlar. Lazzari nos remete ao personagem bíblico ressuscitado por Jesus e, assim como o homem de Betânia, era também humilde não só na hierarquia do forte, mas também por sua origem, pois a patrulha que foi resgatar seu cadáver observou que ele tinha as mãos fortes de um camponês. Porém um Lázaro buzzatiano jamais teria sua vida de volta. A sentinela que o executou chama-se Martelli ${ }^{13}$,

\footnotetext{
${ }^{11}$ Sobrenome derivado do adjetivo matto, em português louco, insano.

${ }^{12}$ Sobrenome que se utiliza do substantivo rovina, ruína em português.

${ }^{13}$ Sobrenome criado a partir do substantivo coognato martello.
} 
sugerindo talvez um instrumento de justiça, e sua alcunha, Moretto, diminutivo de Moro $^{14}$, indica alguém diverso, estrangeiro, inimigo; se assim for, este seria um inimigo infiltrado. Monti ${ }^{15}$, sobrenome do capitão que comanda a missão de demarcação de fronteiras, alude aos seus gigantescos aspectos físicos, mas também espirituais (no que diz respeito à esterilidade da rocha).

Pietro Angustina, personagem importantíssima do romance, tem um nome que acena para a sua perene angústia. O chefe dos alfaiates Prosdócimo, segundo Jean Lacroix, pode ter a origem de seu nome no étimo grego prosdok, "espera" (LACROIX, 1992, p. 206-207), e é justamente ele a trazer para Drogo a notícia mais esperada de sua vida, a vinda dos supostos inimigos. O sobrenome do jovem tenente Moro, assim como o apelido de Martelli, também sugere a presença do estrangeiro, do inimigo mouro e não-cristão, no entanto, este não vem do deserto e sim das entranhas do próprio reino, mas o nome Moro também encaixa uma espécie de rima baciata $^{16}$ com o nome de Drogo, sobretudo na situação em que os dois se encontram pela primeira vez, repetindo com extrema exatidão o encontro do jovem Drogo com o capitão Ortiz.

Há outros nomes que aparecem somente uma vez e contribuem na formação de certas isotopias como Bosco, Grotta (bosque e gruta respectivamente) etc, signos que cooperam na instauração de um clima de escuridão, fechamento, limitação, ou da marcialidade como Martini, Forze ${ }^{17}$, etc. Já os ajudantes de Drogo têm nomes que remetem ao divino, como Geronimo (literalmente nome sacro em grego e nome do famoso tradutor da Bíblia para o latim) e Luca (nome de um dos 12 apóstolos de Cristo), ambos mensageiros das verdades cristãs, mas no Deserto são nomes incapazes

\footnotetext{
${ }^{14}$ Gentílico, mouro, não-cristão em português.

${ }^{15}$ Substantivo, montes, montanhas em português.

${ }^{16}$ A poética italiana chama de rima baciata (literalmente rima beijada) as rimas em versos consecutivos.

${ }^{17}$ Nomes que possuem a mesma raiz etimológica de Marte, marcial, força.
} 
de ajudar nosso protagosnista a perceber as armadilhas daquela experiência Chama-se de Simeone aquele que aparenta ser mais velho do que verdadeiramente $\mathrm{e}^{18}$, nome que traz em seu núcleo o princípio de um engodo. Ortiz, sobrenome castelhano do lacônico amigo de Drogo, tem a mesma origem de horto, horta, também com o significado de chácara, quinta, enfim, possessão rural que sugere sedentarismo, homem inadequado a aceitar o chamado para empreender uma viagem nômade e primitiva pelo deserto. Já a mãe e os irmãos de Drogo não têm os nomes mencionados, enquanto que a figura de seu pai seria totalmente suprimida não fosse uma pergunta casual de Matti:

« Ho conosciuto anni fa suo padre, tenente. Un esemplare gentiluomo. Certo lei vorrà fare onore alla sua memoria. Presidente dell'Alta Corte, se non mi sbaglio?»

« No, signor maggiore » fece Drogo. «Era medico, mio padre. »

« Ah, già, medico, perbacco, mi confondevo, medico, sì, sì. » (p. 22).

O diálogo reportado acima é o único exemplo que impede a sintomática extirpação textual da imagem paterna, inibidora e castradora, figura que não pode ser aceita sem algum problema, um outro a quem o protagonista se identifica por oposição, escolhendo profissão e caminho diversos.

Drogo é um nome pelo qual Dino Buzzati parece nutrir grande interesse desde antes de 1940. Segundo Stefano Jacommuzzi, o nome Giovanni Drogo já havia aparecido em um conto de 1936 (revista Il convegno, 25 de dezembro, chamado "La nostra ora") e como pseudônimo do escritor em dois outros contos: "Notizie false" (Omnibus de 22 de maio de 1937) e "L'uccisione del drago"19 (Oggi de 3 de junho de 1939) (Cfr. JACOMUZZI, 1982 p. 118), além da variação Antonio Dorigo, protagonista do romance Un amore de 1963.

\footnotetext{
${ }^{18}$ Cfr. BATTISTI, C. Dizionario etimologico italiano. (5 vol.) Firenze: Barbèra, 1975.

19 O conto "L'uccisione del drago" figura ainda nas coletâneas I sette messaggieri (1942) e Sessanta racconti (1958).
} 
Talvez pela relação com o conto precedente, a Fortuna Crítica costuma aproximar, pela semelhança fônica, Drogo de Drago, nela também encontramos relações de Drogo com droga, sugerindo letargia, torpor, distância da realidade, alguém que vive no mundo do sonho, do devaneio, do íncubo. Sensações que no protagonista encontram seu vértice em capítulos como o IX (em que a geométrica arquitetura da Bastiani e os primitivos encantos do deserto o entontecem, fazendo-o ficar) e XI (o fabular sonho premonitório da morte de Angustina). Mas em se tratando do protagonista, não só o sobrenome, mas também o nome próprio deve ser levado em consideração, pois Giovanni é um dos nomes mais comuns (senão o mais comum) em línguas latinas ${ }^{20}$; nesse sentido, Giovanni representa o homem ordinário, impotente diante de seu destino, esperando inutilmente pela salvação, dando-se conta no fim da jornada de sua pobre condição. Assim, o narrador chama-o de Giovanni Drogo nos eventos mais formais, de Drogo simplesmente nos fatos mais corriqueiros e, quase intimamente, de Giovanni nos momentos de maior tensão emotiva (de fato Giovanni é como o protagonista vem nomeado pela última vez no romance, poucas linhas antes de sua morte).

As patentes dos militares também servem como meio de leitura da passagem do tempo nas personagens. Drogo inicia sua viagem como oficial subalterno (tenente), e tem como colegas Morel, Lagorio, Angustina e mais tarde Simeoni. Como superiores tem os capitães Ortiz e Monti, o major Matti, o tenente-coronel Nicolosi e o coronel Filimore, comandante da fortaleza.

Após a morte do tenente Angustina, mais ou menos no segundo ano da história, descobre-se — mas isso exige um mínimo de atenção — que Ortiz agora é major

\footnotetext{
${ }^{20}$ Giovanni, italiano; João, português; Juan, espanhol; etc.
} 
(capítulo XVI), detalhe que a princípio não causa nenhum alarde, porém, quando a guarnição é reduzida em seu efetivo e inclusive seu comandante é transferido, toma seu posto um tenente-coronel, Nicolosi. Este fato é um claro sinal de que a Bastiani começa a perder importância, processo que, no entanto, demanda certo tempo.

Quando a estrada é finalmente concluída - encontramo-nos em meados do vigésimo ano da fábula -, observamos que todos os homens do forte avançaram na hierarquia militar e o protagonista agora é capitão, Simeoni major, Ortiz tenente-coronel e comandante, já superiores como Monti e Matti foram reformados, sendo impossível dessa vez ignorar a robusta prova que as promoções representam.

Porém este aspecto revela-se já no segundo capítulo do romance, num diálogo entre Drogo e Ortiz:

Ortiz disse: «Viene dall'Accademia reale, no? ».

«Sissignore, dall'Accademia. »

« Già, e dica: c'è ancora il colonnello Magnus? »

« Colonnello Magnus? Non mi pare, non lo conosco. » (...)

Ortiz disse: «E mi dica, tenente. C'è ancora il maggiore Bosco? Fa ancora scuola di tiro?».

«Nossignore, non mi pare, c'è Zimmermann, il maggiore Zimmermann. »

«Già, Zimmermann, effettivamente, l'ho sentito nominare. La questione è che sono passati molti anni, dai miei tempi ad oggi... saranno tutti cambiatti oramai. » (p. 14).

Oficias que ingressam, fazem carreira e são reformados através dos tempos, oferecem a Drogo um sinal de alerta, no início de sua viagem sem retorno, algo que o protagonista do Deserto ou não soube ou não pôde ler, pois, das várias mensagens que lhe chegaram de diferentes formas, a mudança das patentes foi apenas mais uma.

O tempo também age sobre o protagonista ao longo das fases de sua vida. No início da trama encontramos o jovem e recém nomeado oficial Giovanni Drogo partindo 
para a fortaleza Bastiani, um moço burguês como qualquer outro, cheio de esperanças no futuro, ansioso para que uma nova fase de sua vida comece, quem sabe melhor do que a anterior, porém, um leve pressentimento o acompanha desde então, um aviso, já no exórdio narrativo, de uma história infectada de algo sombrio em seu núcleo, algo que também que se manifesta na construção sintático-estilística de Buzzati, como vimos na primeira seção de nosso trabalho:

Adesso era finalmente ufficiale, non aveva più da consumarsi sui libri né da tremare alla voce del sergente, eppure tutto questo era passato. Tutti quei giorni, che gli erano sembrati odiosi, si erano oramai consumati per sempre, formando mesi ed anni che non si sarebbero ripetuti mai. Sì, adesso egli era ufficiale, avrebbe avuto soldi, le belle donne lo avrebbero forse guardato, ma in fondo - si accorse Giovanni Drogo - il tempo migliore, la prima giovinezza, era probabilmente finito. (p. 3) [grifos nossos].

Clima habilmente construído por meio de escolhas lexicais que são indícios do destino do protagonista, seja na preferência por um tempo verbal de aspecto duvidoso, seja por inquietantes restrições portadas por conjunções e advérbios, quando não pelo amargo sentido de períodos inteiros.

No encontro com o capitão Ortiz revela ânsia e ingenuidade tipicamente juvenis, já na ocasião em que devia desligar-se da Fortaleza mediante um atestado médico falso, falam mais alto os escrúpulos de uma boa criação, além de também caracterizá-lo o vigor físico e a vaidade da juventude, postas à prova nas corridas de cavalo entre os colegas, força oriunda porém de uma "vitalidade sem criatividade" (MALDONATO, 2001 p. 129). Mas nada mais pueril do que as ilusões e sonhos de glória em supostas batalhas, enriquecidas em detalhes a cada guarda nos muros da fortaleza. Contudo, solicitado pela realidade, o jovem oficial mostra-se um "inetto tra inetti" (CARLINO, 1976, p. 35), um incapaz que não sabe como agir quando algo se move no deserto e, 
assediado pelo medo e pelo orgasmo de que a grande hora tenha chegado, acaba delegando inconscientemente a um subordinado o comando e, ao descobrir tratar-se apenas de um cavalo, e que após estes os Tártaros poderiam finalmente chegar, deseja vilmente que aquilo não passe de um engano, de uma mensagem equivocada vinda do deserto. Seus desejos são ambíguos, situam-se sempre na fronteira entre o ideal desejado e o receio pelo preço que esses possam custar.

Ainda jovem, Drogo sente uma inexplicável atração pelo deserto, uma paisagem pitoresca, uma grande extensão uniforme de uma planície árida e estéril. Mas à esterilidade do deserto se opõe sua extrema fertilidade simbólica. A observação do deserto despertou em Drogo, sem que ele se desse conta, seus mais primitivos instintos, sua necessidade essencial de operar a travessia, o êxodo, como os primitivos nômades a fim de encontrar, na imensa planície onde tudo é indiferenciado, inclusive, a realidade, o sentido que sempre buscou para sua pobre vida.

O deserto lhe desperta recônditos desejos de buscar a verdade onde não há habitantes, não há traços de civilização, buscar, naquela imensa desolação, a paz interior que buscavam os eremitas e os monges, encontrar, na enorme solidão, a si mesmo. $\mathrm{O}$ deserto é o local da amplitude, aberto a grandes possibilidades de sentido, uma extensão da qual é impossível precisar o limite, onde ao calor e à extrema claridade do dia se sucedem o frio e o negrume da noite e nele o tempo parece não existir. O jovem oficial nada disso sabia, mas seu espírito foi assaltado por esse silencioso chamado à viagem primordial, ao qual jamais atendeu, por inércia, por inépcia ou mesmo pela falta de autoconhecimento, decisão que lhe legará, por toda vida, aquele indistinto sentimento de angústia. 
A morte de Angustina, porém, oferece a Drogo a primeira grande oportunidade de perceber o resultado da ação do tempo. Envolvido na "dinâmica" do serviço e entregue ao tempo público e datável da Bastiani, o protagonista não se dá conta de que o verdadeiro tempo, o tempo fundamental, é o que leva ao último horizonte da existência, o impulso primitivo para a morte, e não aquele que regula compromissos sociais e turnos de guarda. A existência de Drogo é dominada pelo tempo cronológico, um tempo externo, de outra natureza, pois o tempo interior nele não conta, não tem espessura nem profundidade, o que o define, nesse sentido, como alguém de personalidade rasa, enfim, uma personagem tipo, adequada àquela paisagem sempre igual, sem mudanças bruscas ou de qualquer espécie, apenas calor e extrema claridade durante o dia, frio e negrume à noite.

Angustina era o outro a quem Drogo usava como referência às próprias medidas, mas ele não soube enxergar na morte do colega a própria morte, por isso, ela o pega de surpresa. A tensa relação com o outro, com o duplo, tem papel fundamental para a constituição e tomada de consciência da própria identidade, mas isso por si só não basta.

Ao término da construção da estrada, vemos Giovanni Drogo agora na meiaidade:

In una bellissima mattina di settembre ancora una volta Drogo, il capitano Giovanni Drogo, risale a cavallo la ripida strada che dalla pianura mena alla Fortezza Bastiani. Ha avuto un mese di licenza ma dopo venti giorni già se ne ritorna; la città gli è oramai diventata completamente estranea, i vecchi amici hanno fatto strada, occupano posizioni importanti e lo salutano frettolosamente come un ufficiale qualsiasi. Anche la sua casa, che pure Drogo continua ad amare, gli riempie l'animo, quando lui ci ritorna, di una pena difficile a dire. ( $p$. 200). 
Vinte anos de Fortaleza lhe custaram caro demais. "Quarentão" (CANDIDO, 1990 p. 64), incapaz de se readaptar ao estilo de vida na cidade, não lhe resta outra alternativa que não seja a vida de caserna. Por seu caráter intermediário, esta é uma idade difícil de definir objetivamente mudanças em relação a Drogo jovem, mas, segundo o narrador, “(...) Purtroppo egli non si sente gran che cambiato, il tempo è fuggito tanto velocemente che l'animo non è riuscito a invecchiare." (p. 200). Em outras palavras, tempo interior e tempo exterior têm em Drogo andamentos distintos. Mas o vigor físico, ainda que sutilmente, vai desaparecendo:

Oh, se ci avesse pensato, la prima sera che fece le scale a un gradino per volta! Si sentiva un po' stanco, è vero, aveva un cerchio alla testa e nessun desiderio della solita partita a carte (anche in precedenza del resto aveva qualche volta rinunciato a salire le scale di corsa per via di malesseri occasionali). Non gli venne il più lontano dubbio che quella sera fosse molto triste per lui, che su quei giardini, in quell'ora precisa, terminasse la sua giovinezza, che il giorno dopo, per nessuna speciale ragione, non sarebbe più ritornato al vecchio sistema, e neppure dopodomani, né più tardi, ne mai. (p. 201).

Mais uma vez as escadas voltam como meio de leitura do tempo passado, mas agora de uma maneira diversa, pois ao contrário do caráter estático da leitura do tempo pelo espaço, apresenta-se agora uma possibilidade de apreensão do fenômeno a partir de um evento dinâmico. A reflexão que o narrador faz da relação de Drogo com as escadas é bastante significativa, pois a quase imperceptível mudança de postura em relação aos degraus denotam que a verdadeira mudança não é física, mas psicológica, portanto, com o amadurecimento, parece inútil o desperdício de energia. Tipicamente buzzatiano é o procedimento de apontar o momento preciso de um fenômeno que raramente pode ser descrito com exatidão, como na análoga situação por ele criada em 1936, ao descrever como se dá o fim da infância de Benvenuto Procolo, um dos protagonistas de $\mathrm{Il}$ segreto Del Bosco Vecchio: 
[Vento Matteo a Benvenuto]: «È inutile » disse il vento « devo andare sul serio. Del resto, questa forse è la notte famosa in cui tu finirai di essere bambino. Non so se qualcuno te l'ha detto. Di questa notte i più non si accorgono, non sospettano nemmeno que esista, eppure è una netta barriera che si chiude d'improvviso. Capita di solito nel sonno. Sì, può darsi che sia la tua volta. Tu domani sarà molto più forte, domani comincierà per te una nuova vita, ma non capirai più molte cose: non li capirai più, quando parlano, gli alberi, né gli uccelli, né i fiumi, né i venti. Anche se io rimanessi, non potresti, di quello che dico, intendere più una parola. Udresti sì la mia voce, ma ti sembrerebbe un insignificante fruscìo, rideresti anzi di queste cose. No, forse è meglio così, che ci separiamo al punto giusto. " (BUZZATI, 2007 p. 149).

A infância de Benvenuto e a juventude de Drogo terminam em um momento preciso, há uma rigorosa separação entre antes e depois, entre um ciclo e outro da vida. Esta separação estanque é mormente representada pela figura do grande portão que bloqueia a via de retorno na parábola do sexto capítulo. Talvez por já ter um imenso portão fechado às suas costas, Drogo não tenha sido capaz de compreender a canção da cascata no capítulo $\mathrm{X}$.

À soleira da senilidade Drogo despede-se, para sempre, de seu grande amigo de caserna, Ortiz. Uma despedida que tem, ao invés do peso insuportável de um silêncio extremamente significativo, a interposição de um diálogo banal, que em nada correspondia ao que os velhos oficiais calavam em seus peitos. O medo do incomodo silêncio - que antes de vazio, de nada, representa a plena possibilidade de sentido (ORLANDI, 1993) — os impele a apagar, com palavras tolas, aquilo que o silêncio a cada instante tornava mais opressor e evidente, ou seja, a vida comum desperdiçada em uma doentia esperança, em um eterno adiamento do "começar a viver", de renúncia à vida. Renúncia esta que, porém, representa um traço de identidade que une, decisivamente, os destinos desses dois homens. Entre eles não é necessário revelar a grande ambição, pois o silêncio é muito mais eloqüente. 
Ignorados os parcos sinais singulares, engolidos pelo tempo uniformizante da Bastiani, Drogo inicia seu caminho rumo à inevitável velhice:

Anche il volto di Giovanni cominciava a coprirsi di pieghe, i capelli diventavano grigi, il passo meno leggero; il torrente della vita lo aveva gettato oramai da una parte, verso i gorghi periferici, benché in fondo non avesse neppure cinquant'anni. Drogo naturalmente non faceva più servizio di guardia, ma aveva un ufficio proprio al Comando, attiguo a quello del tenente colonnello Ortiz. (p. 205).

De uma senilidade cheia de sofrimentos e enfermidades, o narrador descreve episódios que beiram o escatológico e, além de doente, Drogo torna-se um velho a quem se pode taxar de impaciente e rabugento em relação aos subordinados, teimoso e renitente quando Simeoni lhe pede para deixar o forte e, finalmente, reinante e orgulhoso ao recusar uma saudação de despedida de seu comandante. Por fim, o oficial que um dia chegou à Bastiani jovem e cheio de esperanças é reduzido a um pobre velho que mal consegue andar ou permanecer ereto e que experimenta ainda o golpe de misericórdia dado por um desconhecido soldado em sua chegada à fortaleza entre os reforços que, ao vê-lo na grande carruagem para enfermos, exclama: "Va comodo, il vecchietto!”. (p. 228).

Somente diante da morte Drogo dá-se conta de que a vida inteira esperou pelo inimigo errado, ou melhor, o inimigo sempre esteve presente, junto dele, dentro dele. Drogo, na verdade, relacionou-se a vida inteira com o tempo de maneira equivocada, ao deixar que sua existência fosse regulada pela ardilosa armadilha do tempo vulgar. Giovanni sentiu por toda a vida as pulsões internas da temporalidade fundamental que nos leva à morte, mas nunca soube interpretá-las, a não ser no fim da viagem em que percebe que a morte é a condição que torna a vida autêntica, nosso impulso primitivo, a forma pela qual identificamos e compreendemos o tempo. 
Para Maldonato, o tempo é algo que está dentro de cada um e é elemento fundador da própria identidade (MALDONATO, 2001, p. 52). Se a identidade é o próprio tempo, o nosso tempo, então nosso maior inimigo é nosso co-habitante, está dentro de nós e somos nós mesmos. As inúteis tentativas de frear a corrida do tempoinimigo são ações que equivalem a tentar esconder-se de si mesmo, empresa impossível e angustiante. O último encontro de Drogo com o grande inimigo, mil vezes protelado pela eterna espera, é um acerto de contas consigo mesmo, do qual, de maneira alguma, poderia fugir.

O narrador, que nos pintou um Giovanni Drogo ingênuo e escrupuloso na juventude, cético na meia-idade e um tanto rabugento e caquético na velhice precoce figuras que descrevem e não "definem" sua personalidade - , nos faz deparar com a afirmação de Pascal de que não há homens mais diversos entre si do que ele próprio em diferentes idades (PASCAL, 1953). A passagem do tempo é uma exigência da construção de uma personagem moderna, que está sempre por se fazer e se modificar, que se revela, pouco a pouco, na dinâmica de suas ações. Porém Drogo em todas as idades conserva intacta a angustiosa esperança de um dia encontrar um sentido para sua pobre vida. 


\section{Considerações Finais}

Na discussão até aqui empreendida muito se falou do privilégio da narrativa em poder organizar o tempo de uma maneira que é impossível na realidade, tratamos também do comportamento do tempo dentro da narrativa, de sua virtuosidade formal. Estas questões, que no início nos ajudaram a levantar os pontos trabalhados, indicaram também um caminho a seguir.

A qualidade de Il deserto dei Tartari enquanto construção artística e literária é também observável com o auxílio de categorias como prolepses, iterações, simetrias, entre outras. A forma como Buzzati dispõe desses recursos no texto nos ajudam a entender seu romance como um construto habilmente organizado, e sua obra literária como processo criativo original que enreda o leitor no labirinto de sua obra, assim como aprisiona as personagens da fortaleza que descortina o deserto (e todas as possibilidades de significação deste) à sua frente.

La fortezza seria o título desse romance, mas foi trocado por conselho do editor Leo Longanesi por estar muito associado à Guerra que acabara de se iniciar ${ }^{21}$. Dissemos, no início do trabalho, que estudar Il deserto dei Tartari sob um ponto de vista é renunciar a outros, por isso declaramos nossa imediata renúncia em não discutir as hoje óbvias relações que a obra-prima de Buzzati tem com o conturbado momento histórico em que foi produzido.

A informação de Giulio Nascimbeni poderia abrir uma outra perspectiva de análise da obra, isto é, apresentar o clima de expectativa funesta dos primeiros anos da maior guerra do século XX e o clima de letargia que dominou o cenário político italiano

\footnotetext{
${ }^{21}$ Cfr. NASCIMBENI, 1982.
} 
durante a ditadura fascista, entretanto, caracteriza-se para nós, no âmbito deste trabalho, unicamente como informação que diz respeito ao processo criativo da obra.

Buzzati construiu uma admirável fortaleza textual, um produto artístico arquitetado com uma consistência concreta. À arquitetura quimérica da Bastiani e à rigidez das normas do seu regulamento correspondem o extremo cuidado em dispor geometricamente os eventos na trama, de modo que a rigidez das simetrias dão consistência textual aos temas desenvolvidos, como verdadeiras vigas a sustentar esta construção. A coesão entre estes temas e sua realização efetiva na superfície textual revela como esta obra de arte pode — e deve — ser lida em diversos níveis da linguagem que proporcionam diferentes possibilidades de significação.

A fortaleza é uma edificação geometricamente estruturada, um complexo arquitetônico organizado a partir da necessidade do homem em se proteger. A estabilidade das formas constrói a ilusão necessária de reparo e proteção ao mundo externo. Mas o que dizer do imenso deserto, espaço indomável por definição? Suas fronteiras são indefiníveis e escapam ao nosso entendimento. O deserto nos desafia, nos causa medo e fascínio, nos convida a domá-lo e a vencê-lo, mas isto não é possível. Sua aparência estéril esconde um mar subterrâneo de fecundidade espiritual, à qual nos sentimos tentados a enfrentar em busca de nossa essência primeira.

Como o deserto toda a extensão narrativa do romance de Buzzati é permeada por imagens de aparência seca, infrutíferas, nas quais mal se podem ver as fronteiras que definem espaços e delineiam as figuras dos homens. Contudo, são riquíssimas as possibilidades de leitura desse texto aparentemente unidirecional, mas, assim como na 
relação com o deserto, a revelação dos muitos significados vem do paciente e humilde exercício de contemplação.

Tratar do tempo, matéria que tanto perturbou Santo Agostinho e que Genette chega a definir como "escabrosa", também não foi para nós tarefa fácil e, admitamos logo, provavelmente não o fizemos a contento. O desafio de tentar entendê-lo, organizálo em categorias inteligíveis não foi - e talvez jamais fosse - vencido, e descobrimos (cedo? tarde?) que não se pode vencê-lo.

O poder devastador que o tempo demonstrou possuir sobre o destino de Giovanni Drogo nem mesmo nos pode servir de alerta. Drogo não é apenas Drogo, ele é, sobretudo, um de nossos incômodos reflexos; refletir-nos é uma das habilidades na qual a literatura é pródiga. Não é fácil admitir-se um Giovanni Drogo, mas não é difícil provar empatia diante de sua pena, embora isto ainda não baste. De nada adianta nossa compaixão para com ele, nem é possível tirar da sua uma nossa lição. Giovanni tem seu inimigo, nós temos o nosso.

Por ora, o desafio chega a seu termo, pois o "tempo público" tem suas demandas e exige término e conclusões precisas. De nossa parte, acreditamos ter demonstrado que as armadilhas do tempo e da construção da fortaleza textual buzzatiana fazem de $I l$ deserto dei Tartari uma obra ímpar na literatura italiana. Ao opor a letargia à ilusão de velocidade e presteza, própria desse século, e ao abrir inúmeras possibilidades de leitura para seu texto, Buzzati firma-se definitivamente na tradição romanesca italiana e mundial do século XX e como artista cuja obra merece um estudo aprofundado nos séculos por vir. 


\section{Bibliografia}

\section{Obras de Dino Buzzati}

BUZZATI, D. Il deserto dei Tartari. Milano: Mondadori, 2004. . Il segreto del Bosco Vecchio. Milano: Mondadori, 2007. . Opere scelte. I Meridiani. Milano: Mondadori, 1998.

\section{Bibliografia Geral}

AGUIAR E SILVA, V. M. Teoria da literatura. Coimbra: Almedina, 1968.

ARENDT, H. A condição humana. Rio de Janeiro: Forense Universitária, 1989.

BACHELARD, G. A poética do espaço. São Paulo: Martins Fontes, 1989.

BAKHTIN, M. M. Questões de literatura e de estética: a teoria do romance. São Paulo: Editora da UNESP, 1993.

BARROS, D. L. P. Teoria semiótica do texto. São Paulo: Ática: 1994.

BARTHES, R. Crítica e verdade. São Paulo: Perspectiva, 1970.

BATTISTI, C. Dizionario etimologico italiano. (5 vol.) Firenze: Barbèra, 1975.

BELlASPIGA, L. “Dio che non esisti ti prego”. In: ,Dino, La faticadi credere. Milano: Àncora, 2006.

BENVENISTE, É. Problemas de lingüística geral. 2vol. Campinas: Fontes, 1995.

BIONDI, A. “Metafora e sogno: la narrativa di Buzzati fra 'Italia magica' e 'Surrealismo italiano"”. In GIANNETTO, N. (org.). Il pianeta Buzzati: Atti del Convegno Internazionale Feltre e Belluno, 12-15 ottobre 1989. Milano: Mondadori, 1992.

CALVINO, I. Lezioni americane: sei proposte per il prossimo millennio. Milano: Mondadori, 2002. 
. Mondo scritto e mondo non scritto. Milano: Mondadori, 2003.

CANDIDO, A. A personagem de ficção. São Paulo: Perspectiva, 1976.

. “Quatro esperas”. In: Novos estudos Cebrap, n. 26. São Paulo, 1990. pp. 49-76.

CARLINO, M. Come leggere "Il deserto dei Tartari” di Dino Buzzati. Milano: Mondadori, 1976.

CARLOS, A. M. O estilhaçamento da moderna Babilônia. Um estudo sobre o conceito de ruptura em A queda da Baliverna de Dino Buzzati. Dissertação de Mestrado. São Paulo: USP, Orientadora: Aurora Fornoni Bernardini.

CAVALliNI, G. Dino Buzzati: Il limite dell'ombra. Roma: Studium, 1997.

CECCHI, E. "Prosatori e Narratori: Dino Buzzati”. In: Il Novecento (tomo secondo). Milano: Garzanti, 1994.pp. 399-402.

DANSTRUP, A. L. "Buzzati e Calvino: due scrittori e due concezioni del fantastico". In GIANNETTO, N. (org.). Il pianeta Buzzati: Atti del Convegno Internazionale Feltre e Belluno, 12-15 ottobre 1989. Milano: Mondadori, 1992.

ECO, U. Lector in Fabula. La cooperazione interpretativa nei testi narrativi. Milano: Bompiani, 1979.

. "O tempo na arte". In Sobre os espelhos e outros ensaios. Trad. De Beatriz Borges. Rio de Janeiro: Nova Frontiera, 1989.

. Sei passeggiate nei boschi narrativi. Milano: Bompiani, 1995.

EIKHENBAUM, B. M (et al). Teoria da literatura: formalistas russos. Porto Alegre: Globo, 1973.

FONTANELlA, A. (org.) Dino Buzzati: Atti del Convegno Internazionale di Studio promosso dalla fondazione Cini. Firenze: Olschki, 1982.

FORSTER, E. M. Aspectos do romance. Porto Alegre: Globo, 1969.

FRYE, N. Anatomia da crítica. São Paulo: Cultrix, 1973. 
GENETTE, G. Figuras. São Paulo: Perspectiva, 1972.

. Discurso da narrativa. Lisboa: Arcadia, 1979.

GEERTS, W. "Forma, spazio visione". In FONTANELLA, A. (org.) Dino Buzzati: Atti del Convegno Internazionale di Studio promosso dalla fondazione Cini. Firenze: Olschki, 1982.

GIANNETTO, N. (org.). Il pianeta Buzzati: Atti del Convegno Internazionale Feltre e Belluno, 12-15 ottobre 1989. Milano: Mondadori, 1992.

GINZBURG, C. Mitos, emblemas, sinais: morfologia e história. São Paulo: Companhia das Letras, 1990.

. Olhos de madeira: nove reflexões sobre a distância. São Paulo: companhia das Letras, 2001.

GREIMAS, A. J. Semântica estrutural: Pesquisa de método. São Paulo: Cultrix, 1976.

GROSSER, H. Narrativa: Manuale e antologia. Milano: Principato, 1986.

HAMBURGER, K. A lógica da criação literária. Sao Paulo: Perspectiva, 1975.

IMBERTY, C. "Il rivale assente". In GIANNETTO, N. (org.). Il pianeta Buzzati: Atti del Convegno Internazionale Feltre e Belluno, 12-15 ottobre 1989. Milano: Mondadori, 1992.

JACOMUZZI, S. "I primi racconti di Dino Buzzati: il tempo dei messaggi". In FONTANELlA, A. (org.) Dino Buzzati: Atti del Convegno Internazionale di Studio promosso dalla fondazione Cini. Firenze: Olschki, 1982.

KOTHE, F. R. A alegoria. São Paulo: Ática, 1996.

LACROIX, J. "Utopie buzzatiene: il racconto dell'altrove”. In GIANNETTO, N. (org.). Il pianeta Buzzati: Atti del Convegno Internazionale Feltre e Belluno, 12-15 ottobre 1989. Milano: Mondadori, 1992.

LUKACS, G. Teoria do romance. Lisboa: Presença, 1988. 
MALDONATO, Mauro. A subversão do ser: identidade, mundo, tempo, espaço: fenomenologia de uma mutação. Tradução de Luciano Loprete e Roberta Barni. São Paulo: Fundação Peirópolis, 2001.

. Raizes errantes. Tradução de Roberta Barni. São Paulo: SESC, Editora 34, 2004.

MANACORDA, G. Storia della Letteratura Italiana contemporânea, 1940 - 1975. Roma: Editori Riuniti, 1979.

. Storia della Letteratura Italiana tra le due guerre, 1919 - 1943. Roma: Editori Riuniti, 1980.

MANZONI, A. I Promessi Sposi. Milano: Mondadori, 1992.

MARCHESE, A. L'oficina del racconto. Milano: Mondadori, 1983.

MENDILOW, A. A. O Tempo e o romance. Porto Alegre: Globo, 1972.

MEYERHOFF, H. O tempo na literatura. São Paulo: McGraw-Hill do Brasil, 1976.

MERLEAU-PONTY, M. Fenomenologia da percepção. São Paulo: Martins Fontes, 1994.

NAMER, F. A; PANAFIEU, Y. "Riflessioni su spazio e tempo in Bontempelli e in Buzzati". InGIANNETTO, N. (org.). Il pianeta Buzzati: Atti del Convegno Internazionale Feltre e Belluno, 12-15 ottobre 1989. Milano: Mondadori, 1992.

NASCIMBENI, G. "Buzzati e i titoli”. In FONTANELLA, A (org.). Dino Buzzati: Atti del Convegno internazionale di Studio promosso dalla fondazione Cini. Firenze: Olschki, 1982.

NOVAES, A. (Org.) Tempo e História. São Paulo: Cia das Letras, Secretaria Municipal de Cultura, 1992.

NUNES, B. O tempo na narrativa. São Paulo: Ática, 2000.

ORLANDI, E. P. As formas do silêncio: no movimento dos sentidos. Campinas: Editora da Unicamp, 1993.

PANCRAZI, P. Scrittori d'oggi: serie IV. Bari: Laterza, 1946. 
PASCAL, B. Páginas escolhidas. São Paulo: Martins Fontes, 1953.

POUILLON, J. Tempo no romance. São Paulo: Cultrix, 1974.

PRALORAN, M. “Il tempo nel romanzo”. In: MORETTI (org.) Il Romanzo. Vol. 2 Le Forme. Torino, Einaudi, 2002

RAWSON, J. "La lingua dei colori in Buzzati”. In GIANNETTO, N. (org.). Il pianeta Buzzati: Atti del Convegno Internazionale Feltre e Belluno, 12-15 ottobre 1989. Milano: Mondadori, 1992.

RICOEUR, P. A memória, a história, o esquecimento. Campinas: Editora da Unicamp, 2007. . (org.) Culturas e o tempo: estudos reunidos pela unesco. Petrópolis: Vozes, 1975. . Tempo e narrativa (Tomo I). Campinas: Papirus, 1994. . Tempo e narrativa (Tomo II). Campinas: Papirus, 1995. . Tempo e narrativa (Tomo III). Campinas: Papirus, 1997.

SEGRE, C. Le strutture e il tempo. Torino: Einaudi, 1979.

SPAGNOLETTI, G. La letteratura italiana del nostro secolo. Volume secondo. Milano: Mondadori, 1985.

TACCA, O. As vozes do romance. Coimbra: Almedina, 1983.

TODOROV, T. As estruturas narrativas. São Paulo: Perspectiva, 1970.

TOSCANI, C. Guida alla Lettura di Buzzati. Milano: Mondadori, 1987.

TRICE, R. Lo spirito europeo e la letteratura italiana. Ventimiglia: Philobiblon, 2005.

VOLPINI, V. Prosa e narrativa dei contemporanei. Roma: Studium, 1967. 